\title{
Plant Species Complexes as Models to Understand Speciation and Evolution: A Review of South American Studies
}

\author{
Fábio Pinheiro, Marcos Vinicius Dantas-Queiroz \& Clarisse Palma-Silva
}

To cite this article: Fábio Pinheiro, Marcos Vinicius Dantas-Queiroz \& Clarisse PalmaSilva (2018) Plant Species Complexes as Models to Understand Speciation and Evolution: A Review of South American Studies, Critical Reviews in Plant Sciences, 37:1, 54-80, DOI: 10.1080/07352689.2018.1471565

To link to this article: https://doi.org/10.1080/07352689.2018.1471565

\section{曲 Published online: 21 May 2018.}

\section{Submit your article to this journal 지}

Llll Article views: 269

View Crossmark data ¿ 


\title{
Plant Species Complexes as Models to Understand Speciation and Evolution: A Review of South American Studies
}

\author{
Fábio Pinheiro (D) ${ }^{a}$, Marcos Vinicius Dantas-Queiroz ${ }^{b}$, and Clarisse Palma-Silva ${ }^{a}$ \\ ${ }^{a}$ Departamento de Biologia Vegetal, Instituto de Biologia, Universidade Estadual de Campinas, Campinas, Brazil; ${ }^{b}$ Departamento de Ecologia, \\ Programa de Pós-graduação em Biologia Vegetal, Universidade Estadual Paulista, UNESP, Rio Claro, Brazil
}

\begin{abstract}
Identifying discontinuous entities within species complexes is a major topic in systematic and evolutionary biology. Comprehensive inventories describing and identifying species rapidly and correctly before they or their habitats disappear is especially important in megadiverse regions, such as South America continent, where a large part of the biodiversity is still unknown and remains to be discovered. Species complexes may account for a substantial number of plant groups in the South American flora, and studies investigating species boundaries in such challenging groups are needed. In this context, multidisciplinary approaches are crucial to understanding the species integrity and boundaries within species complexes. Morphometrics, cytogenetics, anatomy, crossing experiments, and molecular markers have been combined in different ways to investigate species complexes and have helped depict the mechanisms underlying the origin of South American species. Here, we review the current knowledge about plant species complexes on the hyperdiverse South American continent based on a detailed examination of the relevant literature. We discuss the main findings in light of the potential evolutionary mechanisms involved in speciation and suggest future directions in terms of integrating multispecies coalescence methods with several complementary types of morphological, ecological, and geographical data in this research field.
\end{abstract}

\section{KEYWORDS}

Biosystematics; cryptic; species; experimental taxonomy; integrative taxonomy; sibling species; species limits

\section{Introduction}

Species identification, delimitation, and description constitute a long and controversial debate in the fields of systematic and evolutionary biology. Species are the most relevant unit of biodiversity; thus, cautiously deciding how species entities are defined will influence crucial conclusions related to ecological and evolutionary analyses (de Queiroz, 2007; Wiens, 2007; Freudenstein et al., 2017). Furthermore, today's global biodiversity crisis has caused an urgent need for comprehensive inventories describing and identifying species rapidly and correctly before they or their habitats disappear. This effort is especially important in megadiverse regions, such as the South America, where a large part of the biodiversity remains to be discovered, and where the patterns and processes responsible for generating and maintaining the rich biota are poorly understood.

Species delimitation is not always difficult. In cases where speciation occurred a long time ago, newly discovered species will fit into most species concepts. The major difficulty in delimiting species occurs at the beginning of species formation. It is particularly complicated in the following situations: (1) when diversification (or lineage formation) arises with little morphological change, known as cryptic or sibling species (Bickford et al., 2007); (2) when species exhibit extensive morphological diversity (Figure 1) and little genetic divergence, commonly occurring in evolutionary radiations (Shaffer and Thomson, 2007; Barley et al., 2013); or (3) when a subset of populations becomes morphologically and genetically distinct, forming a new lineage from ancestral population types, known as progenitor-derivative speciation (Crawford, 2010; Freudenstein et al., 2017). In these "species complexes," studying species delimitation is most important because we can better understand the first steps of species formation. Furthermore, in species complexes, incomplete knowledge of the biodiversity status of the whole group will lead to erroneous taxon sampling and flawed assessments of biodiversity, biogeography, and speciation processes (Heath et al., 2008).

CONTACT Fábio Pinheiro biopinheiro@yahoo.com.br $@$ Departamento de Biologia Vegetal, Instituto de Biologia, Universidade Estadual de Campinas, Campinas 13083-862, Brazil. 

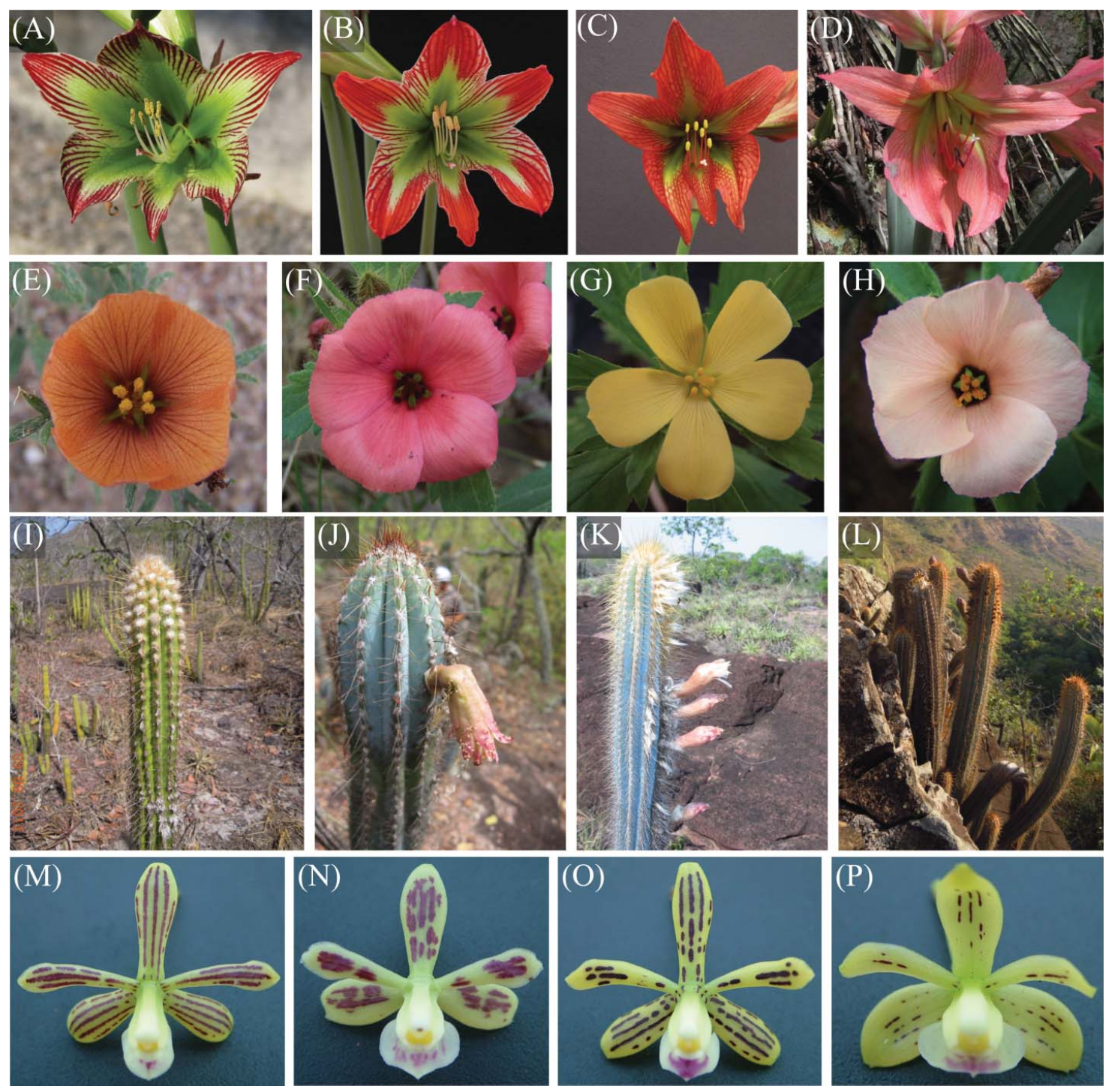

Figure 1. Examples of extensive morphological variability found in plant species complexes occurring within South America. (A-D) Hippeastrum glaucescens Herb. complex (Amaryllidaceae), (E-H) Turnera sidoides Vell. complex (Passifloraceae), (I-L) Pilosocereus jauruensis (Buining \& Brederoo) P. J. Braun complex (Cactaceae), (M-P) Prosthechea vespa (Vell.) W. E. Higgins complex (Orchidaceae). Photo credits: (A-D) Mauro Peixoto, (E-H) Viviana G. SolísNeffa, (I-L) Evandro Marsola de Moraes, and (M-P) Fábio Pinheiro.

The biological species concept, created at the middle of the 20th century (Mayr, 1942), was one of the most influential ideas regarding species delimitation. The definition of species coined by Ernst Mayr (i.e., groups of actually or potentially interbreeding natural populations that are reproductively isolated from other such groups) was influenced by the work of Dobzhansky (1937), who explored the association between barriers to reproductive isolation and species formation. According to this concept, groups of closely related species do not interbreed when growing sympatrically. If hybridization occurs, low hybrid sterility and/or viability would maintain the integrity of the parental species. The biological species concept strongly influenced scientists for generations. Many evolutionary biologists advocated that total reproductive isolation is crucial to maintaining species integrity and thus to recognize different taxonomic entities.

Since the biological species concept was proposed in 1942, many other authors have attempted to formulate alternative definitions to answer the same question: What are species? These alternative concepts have emphasized different sources of data (i.e., morphology assessments, DNA analyses, ecological measures, etc.) and different methods (i.e., morphometry, population genetics, phylogenetics, etc.) to delineate different species concepts. Here, we will not describe these alternative concepts, as this subject has been reviewed intensely in the literature (Luckow and Hortorium, 1995; Mayden, 1997; de Queiroz, 1998, 2007; Wilkins, 2009; Freudenstein et al., 2017). Because different species concepts 
often refer to different stages of speciation, the concepts per se are not mutually exclusive (de Queiroz, 1998). In fact, most of the concepts are complementary, as each has been applied to particular stages of the continuous process of species formation. This idea led the same author to formulate the General Lineage Concept of Species (de Queiroz, 2007), in which species are treated as distinct evolving metapopulation lineages. According to the General Lineage Concept of Species, the former species concepts are treated as operational criteria used to explore the magnitude of evolutionary lineage separation. In this context, there are several advantages to using multiple lines of evidence to explore species delimitation, and some recent reviews on this subject encourage this approach (de Queiroz, 2007; Padial and de la Riva, 2010; Hausdorf, 2011; Carstens et al., 2013; Freudenstein et al., 2017). In addition, few species criteria will support and/ or show full congruence during the early stages of speciation (de Queiroz, 1998), as is often observed in species complexes.

Research in the field of species delimitation and its conceptual changes have been flourishing in the last decades, producing several methods and techniques to achieve this goal (Sites and Marshall, 2003; Knowles and Carstens, 2007; Wiens, 2007; Flot, 2015). Discussion on species delimitation still persists, but today, with the development of informative molecular tools and computational resources capable of processing large amounts of data, the methods have become more meticulous and capable of reconciling the micro- and macroevolutionary dimensions. However, distinguishing among emergent species from populations is especially difficult in species complexes. The line between these two categories is tenuous: divergent species generally do not reach total monophyly, which may be considered gene flow between populations (Naciri and Linder, 2015; Willis, 2017). To overcome such difficulties, multispecies coalescent-based methods have been used, because these approaches do not require reciprocal monophyly of alleles to delimit species, mainly when taxa originate from recent speciation events (Kingman, 1982; Yang and Rannala, 2010). Delimitation methods incorporating multispecies coalescence theory (e.g., BEAST, Heled and Drummond, 2010; BPP, Yang and Rannala, 2010; Yang, 2015; spedeSTEM, Ence and Carstens, 2011; DISSECT, Jones et al., 2015; among others) are already recognized for their empiricism in species complexes (e.g., Carstens and Satler, 2013; Tomasello et al., 2015; Folk and Freudenstein, 2015). Each approach attempts to identify and delimit species via different statistical strategies generally utilizing multiple unlinked loci to reach this goal (for reviews, see Fujita et al., 2012; Camargo et al., 2012).
Using the approach of multiple unlinked loci was important for the development of species tree-based methods and for documenting the important evolutionary role of natural hybridization and speciation with gene flow in species complexes (Nosil, 2008; Jackson et al., 2017). Levin (1978) suggested that biological species are distinct entities generally separated by multiple barriers, which may reduce gene exchange between them. Coyne and Orr (2004) introduced the notion that different species can maintain lower levels of gene exchange without losing their integrity, which was further developed by the idea of "porous genomes" $(\mathrm{Wu}$ 2001). The idea that species can maintain their integrity even in the presence of interspecific gene exchange is crucial in the study of species complexes. In general, incomplete reproductive barriers and gene flow blur species boundaries between sympatric populations, as hybrids may exhibit intermediate morphological characters (Soltis and Soltis, 2009). However, in several cases, parental species maintain their integrity as separate entities, even in cases in which introgression (gene flow) is found. Thus, partial reproductive barriers could be considered the rule, rather than the exception, for most species complexes. Nonetheless, only recently, the coalescent methods for assessing lineage independence have started to explicitly account for gene flow when inferring species boundaries (Chan et al., 2017; Jackson et al., 2017; Morales and Carstens, 2018).

\section{Plant diversity in South America}

Compared with other megadiverse regions, South America is the most biodiverse region on Earth in terms of the number of angiosperm species (Govaerts, 2001). Moreover, South America harbors different plant diversity centers, which surpass 5000 species/10,000 km² (Barthlott et al., 2005). Considering the total number of endemic species observed in 16 megadiverse countries $(145,610), 28 \%$ occur exclusively in South America (Forzza et al., 2012). This high diversity has attracted the attention of the scientific community, which has launched different hypotheses to explain the origin of this diversity (reviewed by Antonelli and Sanmartín, 2011). Much effort has been expended to investigate broad patterns of diversification, using plant phylogenies at higher taxonomic levels to depict the mechanisms involved in plant diversification (Hughes et al., 2013). On the other hand, population-level aspects have received less attention, and little is known regarding microevolutionary mechanisms occurring during the first stages of speciation. Common methods used to investigate species complexes, such as transplant 
experiments (Hagen, 1984) and measures of reproductive isolation in hybrid zones (Baack et al., 2015), have rarely been employed in studies of South American plants. Population-level studies are crucial steps toward understanding speciation mechanisms, as lineages diverge, and incipient reproductive isolation barriers arise, which play an important role in maintaining species diversity (Scopece et al., 2010).

In this context, the study of species complexes plays a crucial role in understanding speciation because our knowledge of this process is incomplete (Via, 2009). Thus, species complexes offer a great opportunity for connecting the micro- and macroevolution scales using coalescent models within a phylogenetic framework (Pons et al., 2006; Knowles and Carstens, 2007; O’Meara, 2010; Yang and Rannala, 2010; Ence and Carstens, 2011). Furthermore, the study of species complexes under an integrative analytical approach will be useful for testing the hypothesis of species delimitation and for better understanding the processes that have promoted neotropical diversification (Padial et al., 2010; Fujita et al., 2012; Guillot et al., 2012). Most studies that have used species complexes as models for understanding speciation originated from temperate countries (Briggs and Walters, 1997), and little is known about this issue in tropical regions, particularly South America.

Species complexes may account for a substantial number of plant groups in the South American flora (Figure 1), and studies investigating species boundaries in such challenging groups are needed. Different South American research teams have been working on species complexes, focusing on different plant groups and using diverse sources of data and analytical tools. The main objective of this study was to investigate the way species complexes have been studied on the megadiverse South American continent. Here, we review the current knowledge about plant species complexes in South America based on a detailed examination of the literature, discussing the main findings in light of the potential evolutionary mechanisms involved in speciation. Specifically, we aimed to (1) review the current knowledge of South American species complexes, (2) examine study distribution among plant groups, (3) investigate the main approaches, sources of data, and analytical tools used to study such groups, and (4) discuss future directions to stimulate this approach as a primary choice for those interested in understanding speciation mechanisms in highly diverse plant groups to guide future studies in the field.

The database used for this review was compiled by conducting searches in the Web of Science ${ }^{\circledR}$ (Institute of Scientific Information, Thomson Scientific). We searched articles published from 1900 (initial coverage of the Web of Science database) to June 2016, combining the key phrases: 'South America' and "species complex" and/or "cryptic species" and/or "sibling species" and/or "species flock." These phrases needed to be cited in the title, abstract, keywords, or the main body of the article. We filtered only studies performed only with angiosperms and excluded studies of invasive species in their nonnative ranges. In addition, we performed a nonexhaustive Google Scholar database search with the same terms (Table 1). We recorded the following information for all articles retrieved: genus and family names; habit; number of populations sampled; whether a multidisciplinary approach was adopted (i.e., molecular, morphometry, cytogenetics, anatomy, etc.); the inclusion of taxonomic decisions; main research fields involved in the study; and main analytical tools adopted when using molecular markers. Traditional taxonomic methods based mainly on analyses of qualitative diagnostic characters, morphometry using quantitative characters, anatomy, cytogenetics, and transplant and crossing experiments, as well as other ecological analyses, such as pollination, phenology, niche models, and molecular markers, were the main research fields considered in this study. Studies using molecular markers were further classified according to three main analytical strategies of phylogenetic, population genetic, and phylogeographic methods. We used the chi-square test with Yates correction to assess the strength of the associations between adopting a multidisciplinary approach and including taxonomic decisions regarding the species complexes. The same test was also used to explore associations between individual data types (e.g., molecular data alone) and taxonomic decisions. Descriptions of new species and the splitting and/or lumping of current species groups were all interpreted as taxonomic decisions to clarify the taxon delimitation within the species complexes. Associations among different research fields were summarized into a network calculated using Gephi software (Bastian et al., 2009).

The Web of Science ${ }^{\circledR}$ and Google Scholar survey of the literature from 1900 to June 2016 identified 129 articles matching our criteria (Table 1). The first study that used one of the reference phrases was published in 1968. Studies were performed on 44 different plant families and 84 genera. Overall, the studies included a range of plant species, from herbs (89 studies), trees (23 studies), lianas (12 studies), and shrubs (8 studies); yet, they still are not a taxonomically representative sample of plant species from South America. Approximately 70\% of the studies were concentrated in 13 families. The seven most studied families were Fabaceae (13), Orchidaceae (13), Poaceae (13), Solanaceae (12), Asteraceae (9), Turneraceae (6), and Bromeliaceae (5) (Figure 2). 
F. PINHEIRO ET AL.

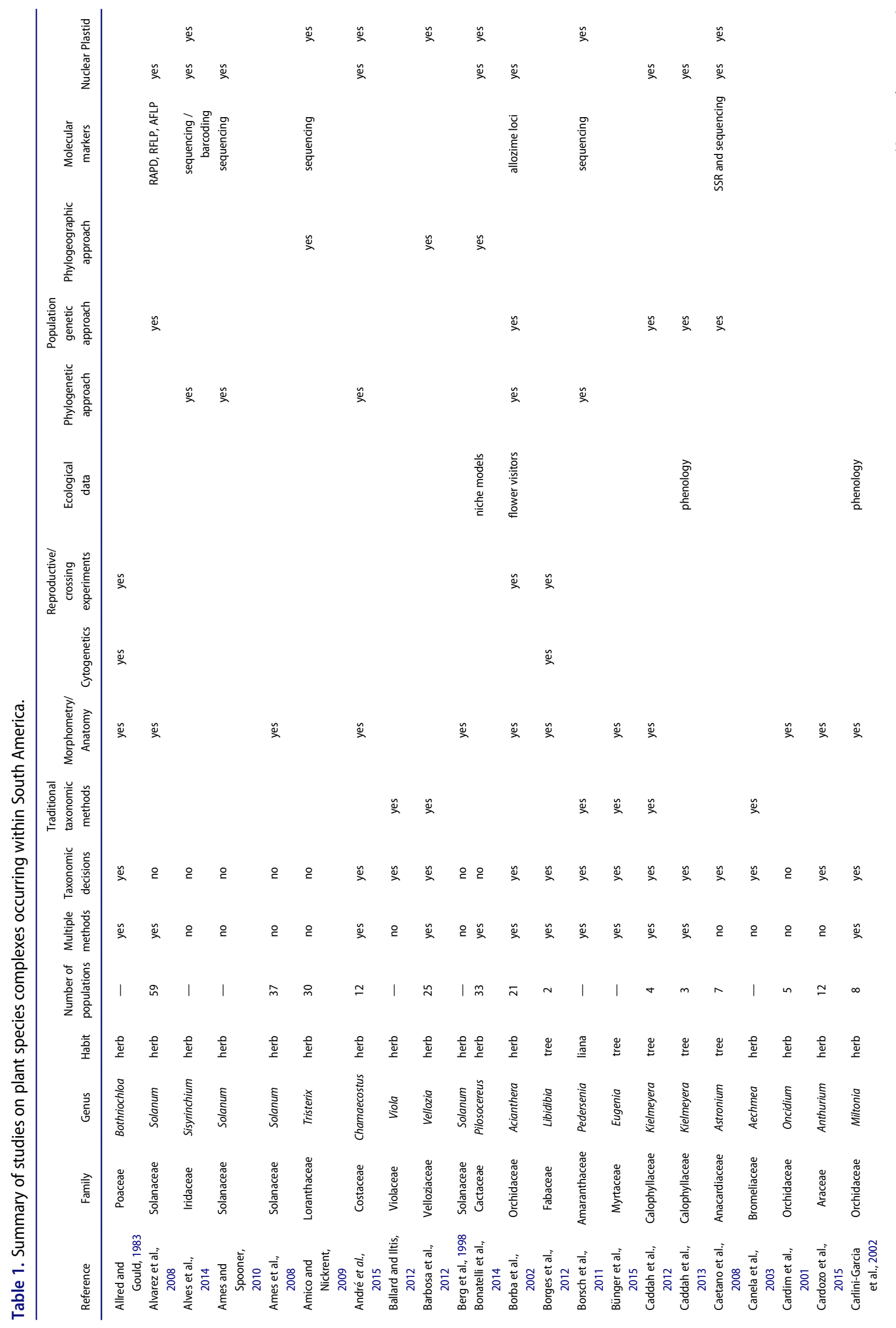


CRITICAL REVIEWS IN PLANT SCIENCES -59

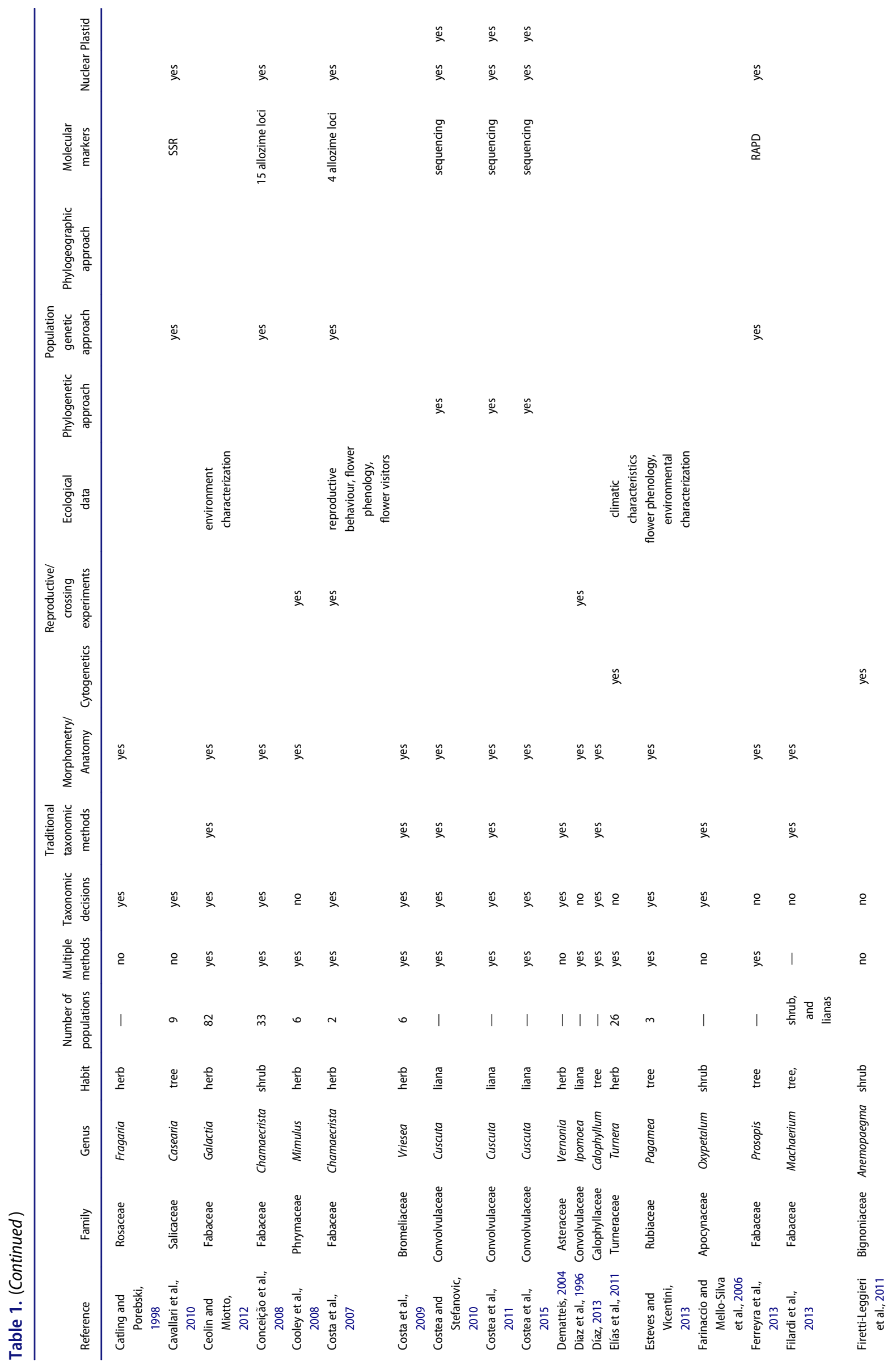


$60-$ F. PINHEIRO ET AL.

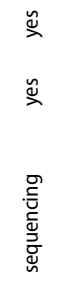

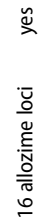

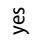

$\stackrel{๗}{\searrow}$

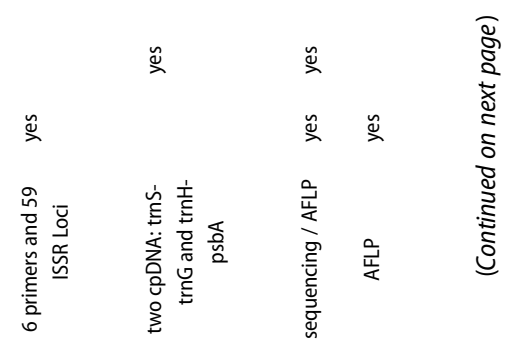

ฆ

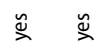

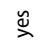

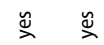

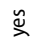

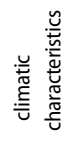

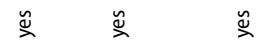

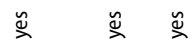

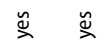

$\stackrel{ฆ}{2}$

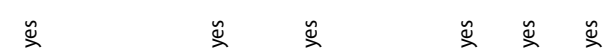

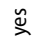

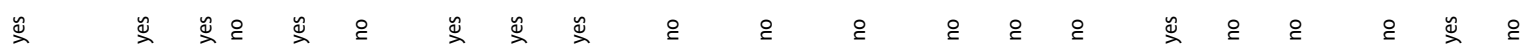

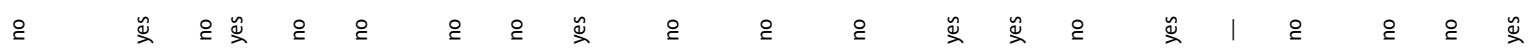

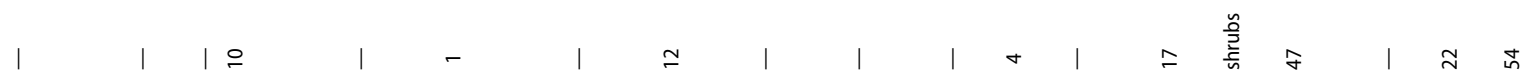

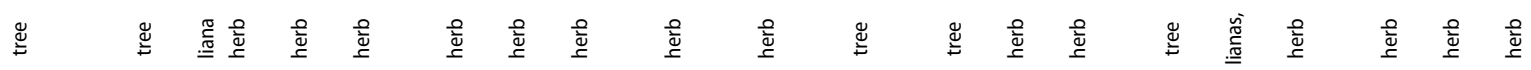

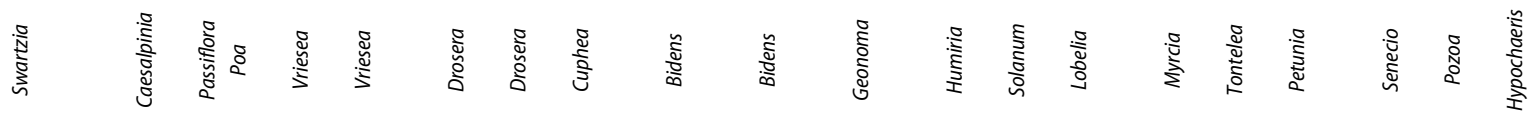

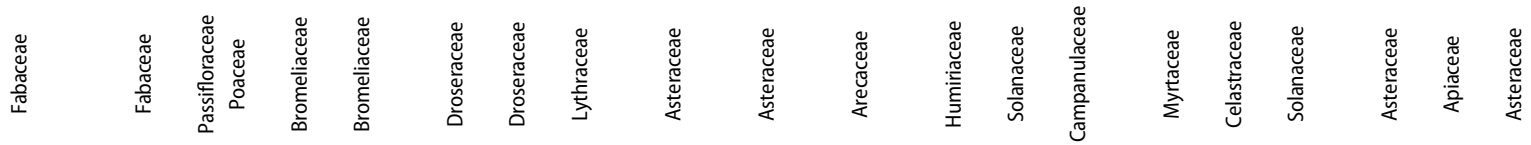

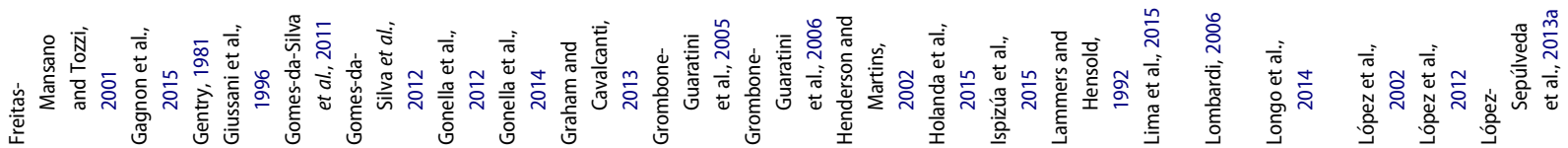


CRITICAL REVIEWS IN PLANT SCIENCES -61

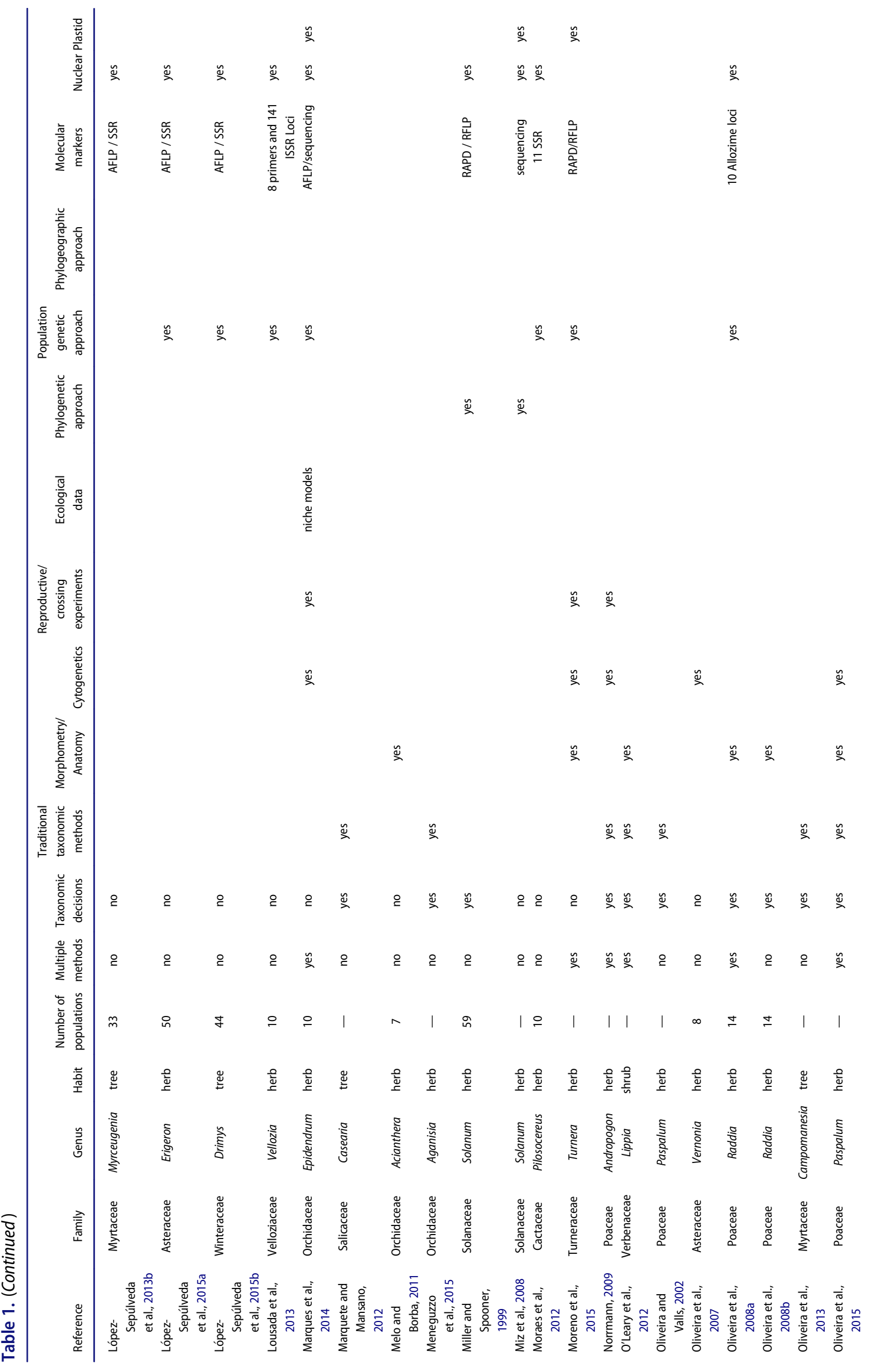


$62 \Leftrightarrow$ F. PINHEIRO ET AL.
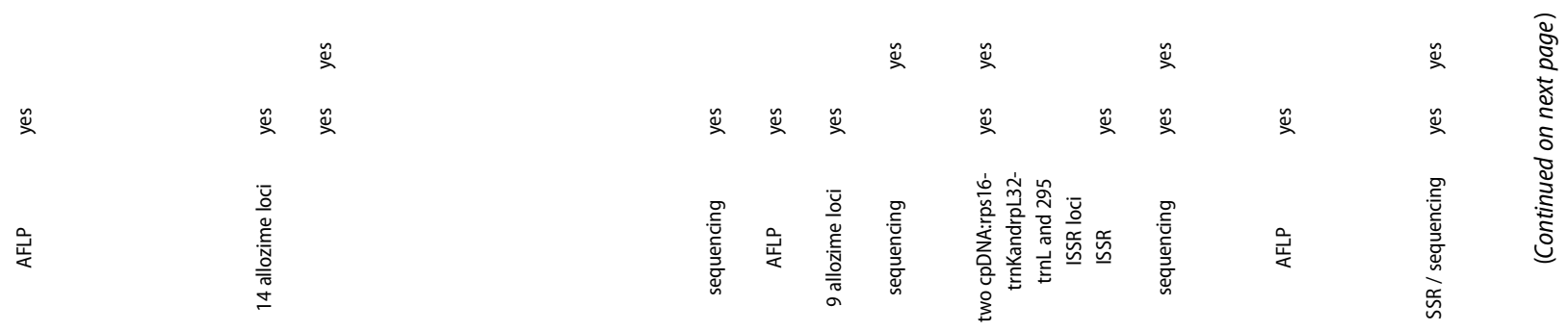

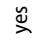

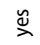

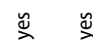

ญ

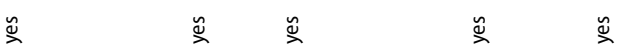

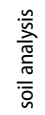

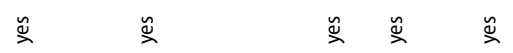

$\stackrel{๗}{\Perp}$

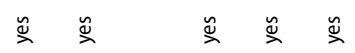

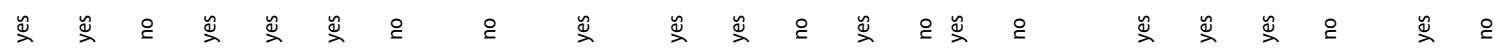

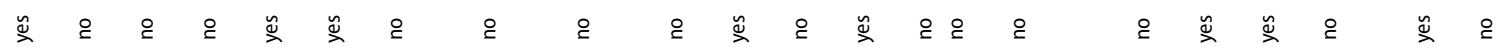

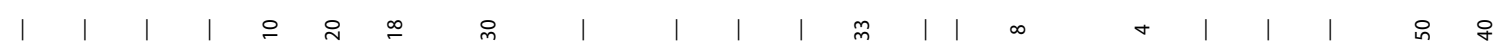

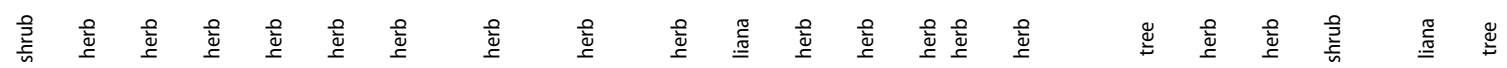

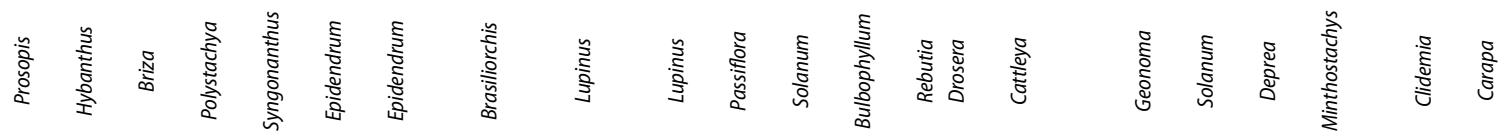

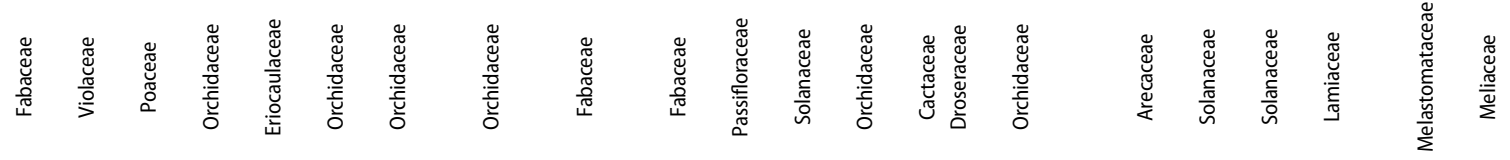

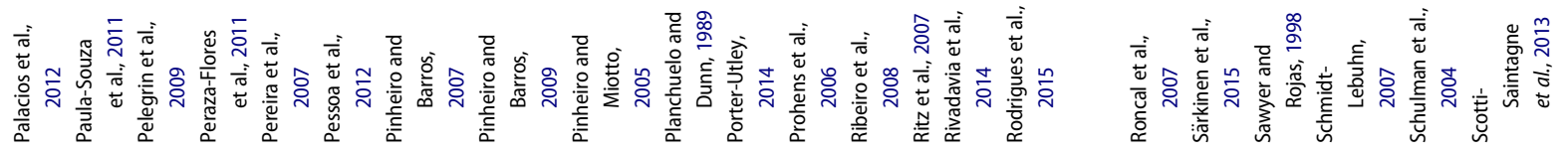


CRITICAL REVIEWS IN PLANT SCIENCES -63

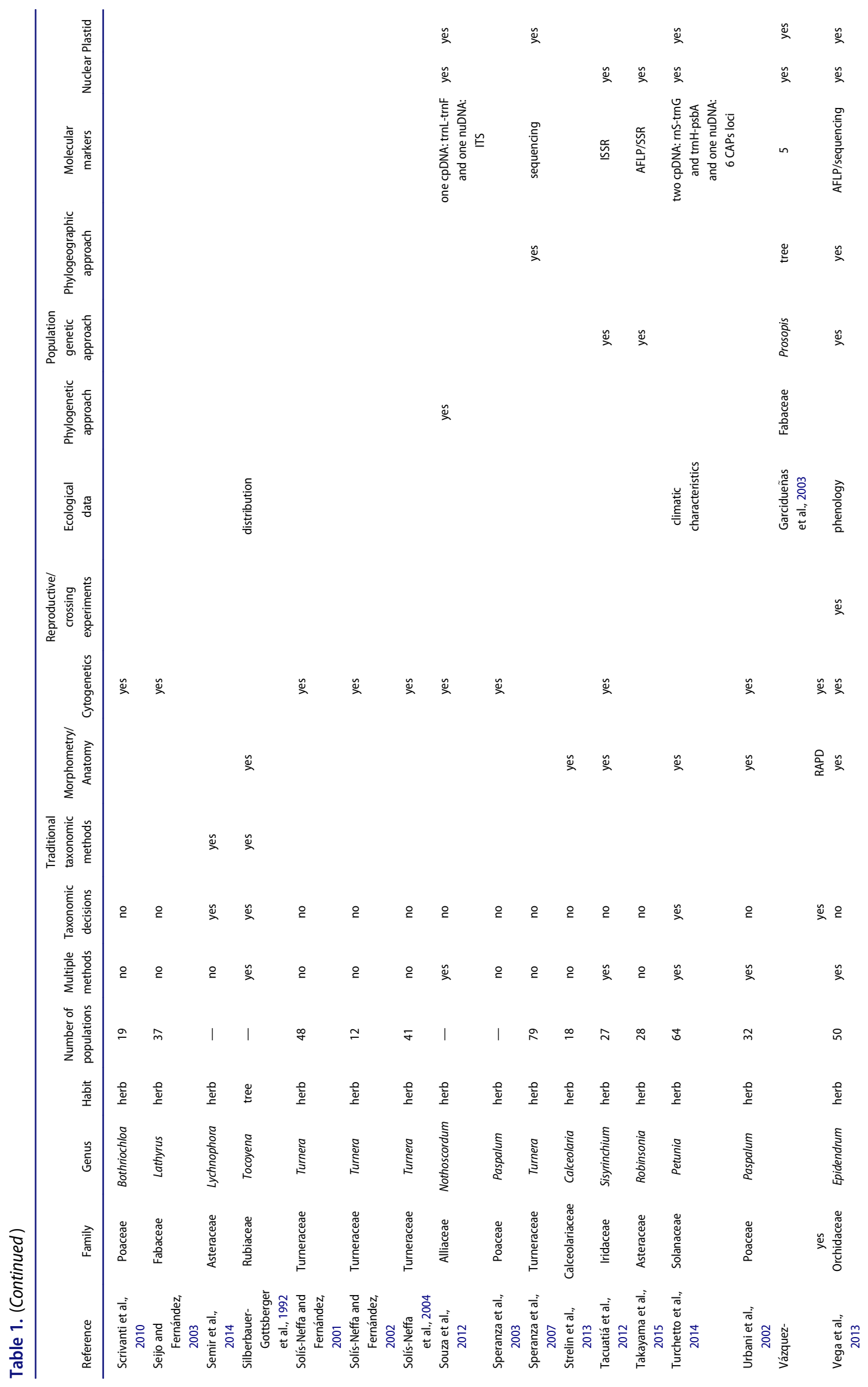


$64 \fallingdotseq$ F. PINHEIRO ET AL.

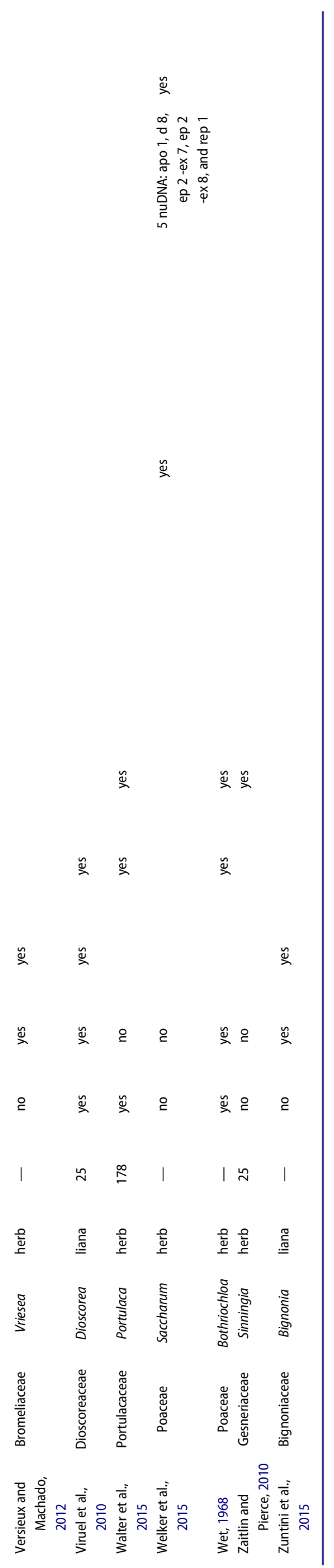




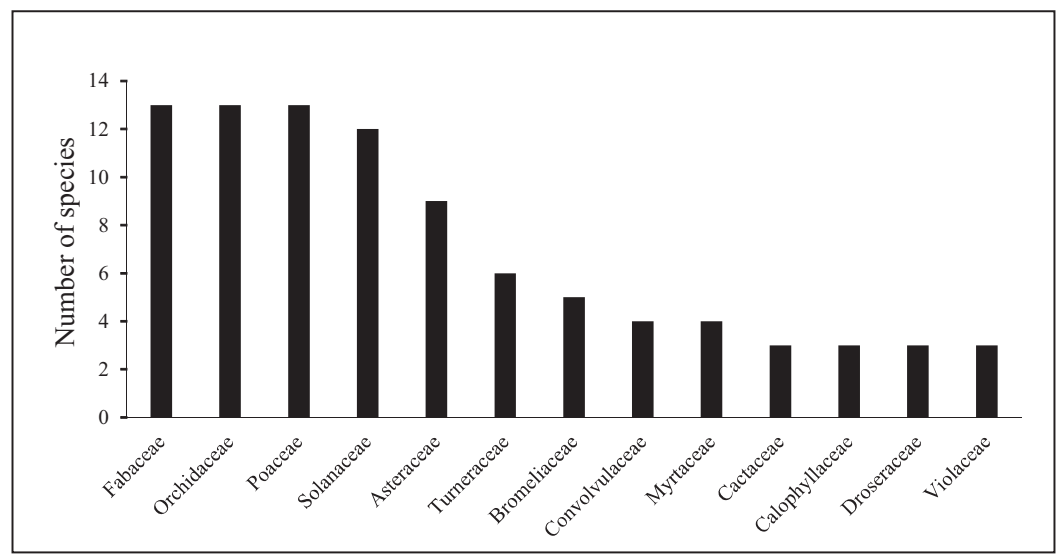

Figure 2. The best represented plant families considering studies of species complexes performed within South America.

Similarly, most of the genera were studied only once, and only $28 \%$ were studied more than once (Table 1 , Figure 3). The use of molecular markers was the most common approach, adopted by $42.6 \%$ of the studies, followed by morphometry (37.9\%) and traditional taxonomy (35.6\%) (Figure 4). Cytogenetic analyses, mostly meiotic and/or mitotic chromosome counting, were performed in $22 \%$ of the studies. Genome sizes estimated using flow cytometry were assessed in four papers. Karyotypes were analyzed in three studies. Cytogenetic molecular techniques (such as in situ hybridization) were used in one of the studies retrieved in our review. Ecological data were used in 14 studies, encompassing different methods, such as phenological analyses (5), climatic variables (5), niche models (2), pollination ecology (2), and soil analysis (1). Anatomy was used in $9.3 \%$ of the studies.

A large number of the studies used molecular markers (42.6\%). Of those, $56.4 \%$ employed population genetic methods to analyze the data, whereas $36 \%$ used phylogenetic approaches, and only $12.7 \%$ used phylogeographic analyses to delimit species (Figure 5A). Eighteen studies combined nuclear and plastid data. Nuclear markers were the primary choice in studies that used molecular markers $(87.3 \%)$, and plastid markers were used by $45.4 \%$ of the studies (Figure 5B). Among the molecular markers used, sequences from different intergenic regions were used most commonly (23 studies); however, most of these studies used few plastidial regions, usually one or two, and only three studies used four or more plastidial regions (López et al., 2012; Vega et al., 2013; Marques et al., 2014). The majority of studies (11 cases) evaluated only a single-copy nuclear locus, in contrast to three studies that evaluated at least four unlinked nuclear loci (Ames and Spooner, 2010; Andre et al., 2015; Welker et al., 2015). Dominant markers, such as random amplification of polymorphic DNA, amplified fragment length polymorphism, and intersimple sequence repeat, were applied in 20 studies. Co-dominant and unlinked nuclear microsatellite loci and allozyme loci were assessed in 11 and 7 studies, respectively (Table 1).

Less than half of the studies (43.4\%) used more than one source of data to analyze species complexes. However, a significant proportion of studies that used a multidisciplinary approach also included taxonomic decisions associated with the species complexes investigated $\left(69.6 \%\right.$, d.f. $=1, \chi^{2}$ [Yates corrected] $=8.529, P<$ $0.01)$. Considering only studies that adopted only one

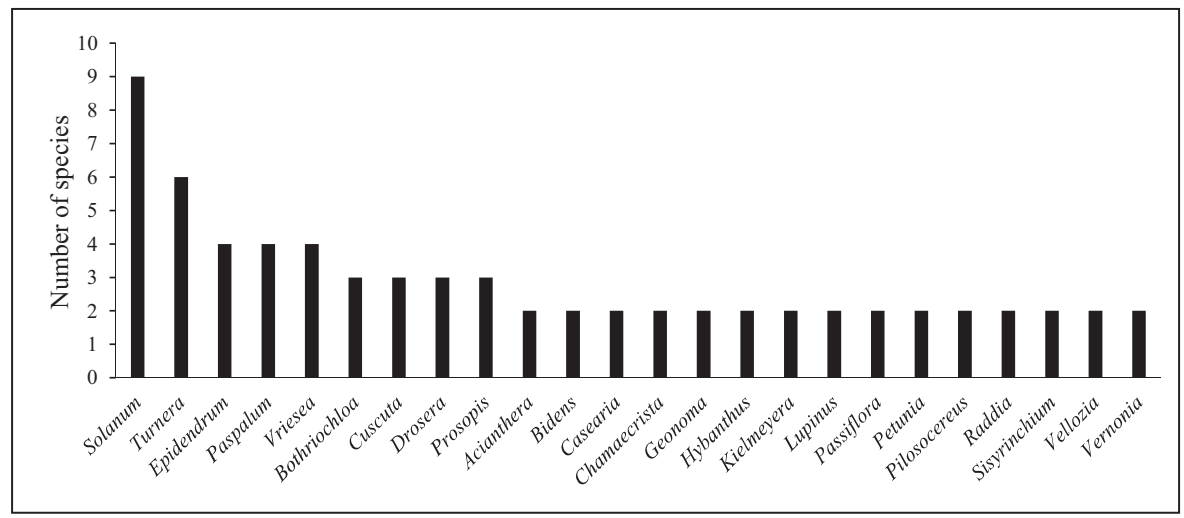

Figure 3. The most well-represented represented plant genera in studies on species complexes in South America. 


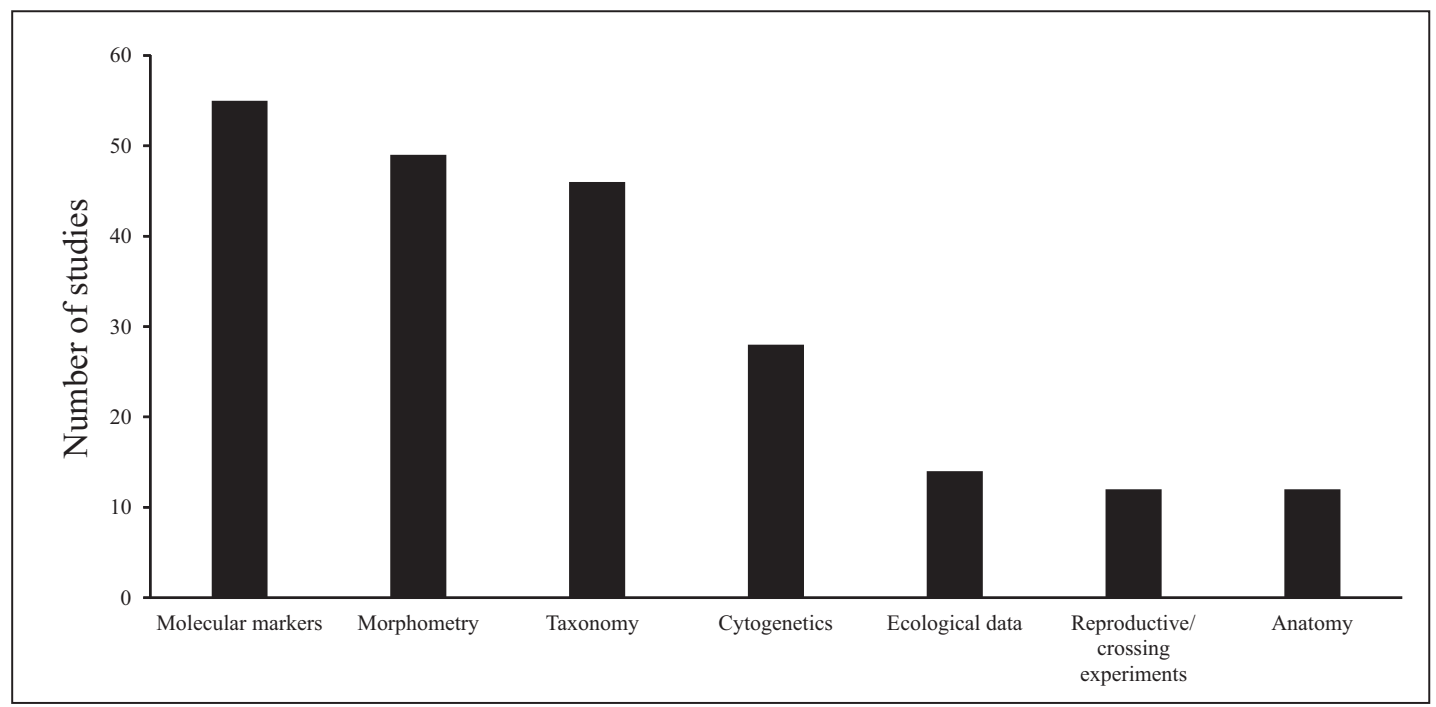

Figure 4. The most widely used methods in studies of species complexes performed within South America.

data type, the use of traditional taxonomic methods always resulted in taxonomic decisions $(100 \%$, d.f. $=1$, $\chi^{2}$ [Yates corrected] $=42.476, P=0.00$ ). The use of molecular markers alone was negatively associated with the adoption of taxonomic decisions [79.1\%, d.f. $=1, \chi^{2}$ [Yates corrected] $=6.355, P<0.05]$, and a similar pattern was detected in studies that used only cytogenetics $\left[100.0 \%\right.$, d.f. $=1, \chi^{2}$ [Yates corrected] $=9.179, P<$ $0.01]$. Taxonomic decisions were not significantly associated with studies that used morphometry $[27.2 \%$, d.f. $=$ $1, \chi^{2}$ [Yates corrected] $=0.76, P=0.383$ ]. Associations between the presence of taxonomic decisions and studies using anatomy, reproductive experiments, and ecological data were not assessed due to the low number of studies in these categories.

According to the network (Figure 6), among the studies that adopted a multidisciplinary approach, molecular markers were used 31 times and were combined more often with morphometry (19), morphologic taxonomy (10), and ecological data (7) (Figure 6). Other common associations between research fields were taxonomy and morphometry (12 studies), taxonomy and molecular markers (10 studies), morphometry and cytogenetics (9 studies), and morphometry and ecology (9 studies, Table 2). In contrast, ecological, anatomical, and cytogenetic studies showed considerably less interaction with other disciplines. Reproductive/crossing experiments and ecological data were never used as a unique source of information to study species complexes and were always combined with other research fields.

The study of species complexes deserves special attention because of the potential to reveal novel and informative results. Most species complexes are potentially composed of recently diverged lineages, which may provide important information regarding the first steps in species radiation, such as colonization of new habitats (Lagomarsino et al., 2016) and selective pressures in different environments (Simon et al., 2011). Owing to their importance, studies of species complexes have guided most of the research on species variation from
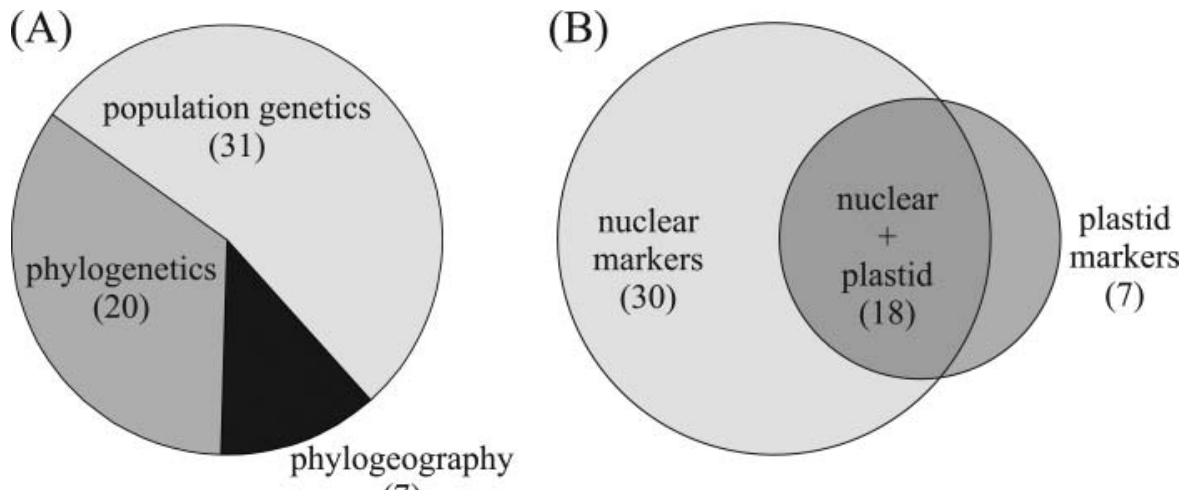

(7)

Figure 5. The main methods used to analyze molecular data in studies of species complexes (A) and the types of markers used in these studies (B). Numbers within parentheses indicate the numbers of studies. 


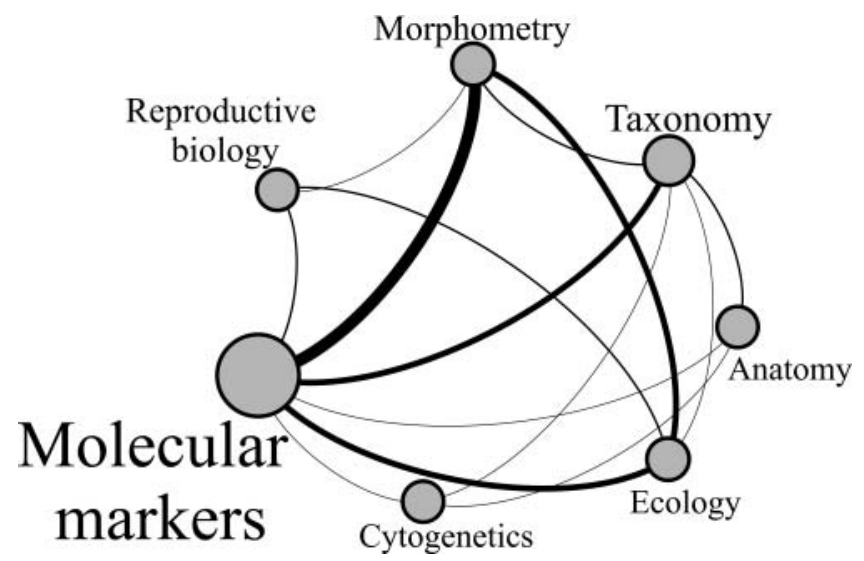

Figure 6. Network showing connections between research fields addressed in studies of species complexes, when adopting a multidisciplinary approach. The size of the circle is proportional to the number of studies in each field, and the line thickness is proportional to the number of connections between fields. See Table 2 for details.

morphological to molecular traits. Thus, these species groups may serve as models to understand speciation events, mainly in the Neotropical region, where mechanisms of species formation remain poorly understood (Antonelli and Sanmartín, 2011). The patterns observed here revealed strong discrepancies among studies of species complexes in South America, showing that such studies have preferentially focused on a few plant families and genera (Table 1). Many studies have been performed on orchids, legumes, and grasses, which are families with great economic importance. Surprisingly, no studies on Euphorbiaceae or Malvaceae species were detected by our survey. Melastomataceae, which is one of the richest plant families in South America, was addressed by only one study (Figure 2). A strong

Table 2. Number of connections between different research fields in studies of species complexes performed in South America. Details are show in Figure 6.

\begin{tabular}{llc}
\hline Source & \multicolumn{1}{c}{ Target } & Number of interactions \\
\hline Anatomy & Cytogenetics & 4 \\
Anatomy & Molecular markers & 4 \\
Anatomy & Morphometry & 4 \\
Anatomy & Reproductive biology & 3 \\
Cytogenetics & Molecular markers & 5 \\
Cytogenetics & Morphometry & 9 \\
Ecology & Molecular markers & 7 \\
Morphometry & Ecology & 9 \\
Morphometry & Molecular markers & 19 \\
Morphometry & Reproductive biology & 8 \\
Reproductive biology & Ecology & 4 \\
Reproductive biology & Molecular markers & 5 \\
Reproductive biology & Cytogenetics & 7 \\
Taxonomy & Anatomy & 6 \\
Taxonomy & Cytogenetics & 3 \\
Taxonomy & Ecology & 3 \\
Taxonomy & Molecular markers & 10 \\
Taxonomy & Morphometry & 12 \\
Taxonomy & Reproductive biology & 1 \\
\hline
\end{tabular}

disparity was also observed among the methods chosen by different studies, which focused on molecular markers, morphometry, and traditional taxonomy (Figure 4). Although, most studies were performed using only one line of evidence (Table 1), taxonomic decisions were significantly associated with studies that used a multidisciplinary approach. We explored the patterns identified by our survey to provide a clear picture of studies of species complex and help guide future efforts in this field.

\section{Taxonomic bias}

Most of the studies on plant species complexes focused on the most diverse plant families found in South America (Figure 2). For example, six of the most studied plant families were also included among the top 10 most diverse families found in Brazil (Zappi et al., 2015). The Orchidaceae family has been a focus of morphological variation studies since Darwin (1882). Large living collections in scientific institutions and of amateur orchidologists have stimulated studies of species complexes worldwide, particularly in Brazil (Pinheiro and Barros, 2007). The same effect is evident in studies on Bromeliaceae (Costa et al., 2009). With some exceptions (Costa et al., 2007; Oliveira et al., 2015), most studies performed on Fabaceae, Poaceae, Solanaceae, and Asteraceae focused on economically important genera. For example, most Solanaceae studies focused on tuber-bearing Solanum L. (potato) species (Figure 3). Grasses commonly used for animal pastures, such as Paspalum L. and Bothriochloa Kuntze, have also been studied extensively. These families show extensive advantages in the study of species complexes, such as short life cycles, ease of cultivation and manipulation in crossing experiments, and high availability of molecular markers.

\section{Use of molecular markers to investigate species complexes}

Studies using molecular markers also showed a preference for population genetic methods (Figure 5A). In many cases, these studies commonly reflected associations between the botany and genetics departments of different institutions (Moraes et al., 2012; Caddah et al., 2013). In these studies, genetic differentiation among populations and lineages was crucial to identify the existence of different species. Use of highly informative markers such as microsatellites, coupled with Bayesian assignment methods (i.e., Pritchard et al., 2000), holds great promise for studying species delimitation and speciation processes. For example, Moraes et al. (2012) and Caddah et al. (2013) depicted complex patterns of 
variation, enabling recognition of divergent lineages that did not correspond exactly to the species limits traditionally recognized. For instance, hybridization between Kielmeyera coriacea Mart. and K. grandiflora A.St.-Hil. has blurred species boundaries and challenged the identification of species throughout history (Caddah et al., 2013). The long-term isolation of Pilosocereus aurisetus (Werderm.) Byles \& G.D. Rowley populations may have promoted divergence of narrow endemic lineages, which occur in a naturally fragmented landscape that imposes strong restrictions on gene exchange and enhances genetic drift (Moraes et al., 2012). Similar patterns were observed in two studies on Asteraceae, which is endemic to oceanic islands, in which multiple events of lineage divergence were driven by strong restrictions on gene exchange (López-Sepúlveda et al., 2013a; Takayama et al., 2015).

Nuclear markers have been highlighted as ideal for interspecific comparisons and have been useful for testing hypotheses of species delimitations (Palma-Silva et al., 2011). Molecular markers with higher levels of gene flow are less prone to introgression and thus more effective for species delimitation (Petit and Excoffier, 2009). In angiosperms, nuclear genomes are usually inherited biparentally and dispersed (from seed and pollen grains), unlike plastidial genomes, which are usually only maternally inherited and dispersed from seeds. This led us to expect that nuclear markers, in angiosperms, would be more suitable for species delimitation than plastidial markers. In fact, most studies that we identified here used nuclear markers (Figure 5B) and conducted better species delimitation in Sisyrinchium (Alves et al., 2014) and Astronium (Caetano et al., 2008). On the other hand, plastid markers show lower levels of gene exchange, often reflecting patterns of geographic isolation (Bonatelli et al., 2014; Turchetto et al., 2014). Furthermore, using plastidial markers exclusively may be problematic because they have limited utility for many of the coalescent methods, as the chloroplast represents only one locus. In addition, divergence among nuclear and plastidial markers could occur as a consequence of hybridization among species, as reported for two species complexes in the Cuscuta genus (Costea et al., 2011, 2015). Thus, despite that only $32 \%$ (18) of studies in our review used a combination of both genomes, authors should attempt to combine both nuclear and plastidial markers when studying species complexes to provide a clearer picture of the species boundaries, and processes involved in their diversification.

One interesting approach employed to investigate species complexes using molecular markers is the "blind sampling" strategy, described by Duminil et al. (2006). In special cases, such as species with a short flowering period and/or a lack of morphological diagnostic characters, authors suggest skipping previous morphological identification methods performed by most studies and proceeding directly to molecular genetic analyses when studying species complexes. Some studies identified in our review adopted the same strategy and were able to identify the species effectively a posterior (Caetano et al., 2008; Marques et al., 2014; Gagnon et al., 2015). However, it is worth mentioning that without appropriate recording of phenotypes, it is presumably more difficult to identify lineages based on previous hypotheses in the literature or translating results into taxonomic updates.

\section{Multidisciplinary approaches}

One advantage of adopting a multidisciplinary approach is the possibility of identifying potential mechanisms underlying the diversification and speciation processes within species complexes. In fact, data from multiple sources can form a reciprocal illumination (Hennig, 1966; Blaxter, 2004; Sukumaran and Knowles, 2017), in which different disciplines inform and refine others. In this context, all sources of data are combined to help describe the diversity of life. For example, despite the efficiency of molecular markers in describing levels of biodiversity and evolutionary relationships, studies using this approach exclusively have limited the explanatory power regarding the mechanisms leading to speciation (Lipscomb et al., 2003; Huang and Knowles, 2016). According to Lipscomb et al. (2003), a multidisciplinary approach has the power to expose inconsistencies, which is an important means of identifying important evolutionary processes, such as hybridization and introgression, and phenotypic convergent plasticity. In fact, recent studies have emphasized the importance of integrative approaches in species delimitation (de Queiroz, 1998; Padial and de la Riva, 2010; Puillandre et al., 2012; Zapata and Jiménez, 2012). This trend was detected based on taxonomic decisions, which were significantly associated with studies that employed different methods. Species complexes are often composed of recently diverged lineages, in which the speciation process is incomplete. In such situations, using a single method may not be sufficient to detect the mechanisms involved in lineage divergence (de Queiroz, 1998). On the other hand, different methods increase the power to detect early stages of divergence, improving further attempts to delimit species.

The joint use of molecular markers and morphometry was observed in 15\% (19 studies) of all retrieved papers (Figure 6). This pattern may reflect the intention of these authors to investigate the extent to which the morphological similarities reflect the evolutionary relationships 
in such groups. This is a fundamental question in species complex studies, as mentioned previously (Briggs and Walters, 1997). In general, the lack of a correlation between morphometric and genetic data is interpreted as evidence of convergent evolution. For example, the results obtained by Borba et al. (2002) support the hypothesis that floral similarities among Acianthera Scheidw. species represent convergence driven by flower fidelity to the same pollinators. Indeed, species with similar flowers are allopatric and show extensive genetic differences (Borba et al., 2002). On the other hand, some studies have found strong correlations between observed morphometric patterns and genetic data. The agreement between morphological and genetic differences has been used to recognize different species within the Chamaecrista cytisoides (Coll) H.S. Irwin \& Barneby complex (Conceição et al., 2008) and within the Chamaecostus subsessilis (Nees \& Mart.) C. D. Specht \& D. W. Stev. complex (Andre et al., 2015).

Crossing experiments were always used in combination with other methods in the studies evaluated in this review (Table 1). Despite the importance of crossability for the biological species concept (Mayr, 1942), such experiments have rarely been used (only $9.3 \%, 12$ papers) to study species complexes in South America. Experimental pollination provides important information regarding mating systems and inbreeding depression (Borba et al., 2011; Sampaio et al., 2012). This information is also crucial to explore the evolution of reproductive barriers among populations and species (Costa et al., 2007; Pinheiro et al., 2013). For example, species with different mating systems may show greater reproductive isolation (Palma-Silva et al., 2015; Pinheiro et al., 2015; Twyford et al., 2015; Neri et al., 2017, 2018). The evolution of reproductive isolation has been central to species recognition since the influential works of Dobzhansky (1937) and Mayr (1942), which articulated the biological species concept. In this context, hybrid zones have been used as natural laboratories to study the evolution of reproductive barriers (Soltis and Soltis, 2009; Baack et al., 2015). However, several studies conducted in hybrid zones have revealed incomplete barriers to gene exchange (Rieseberg et al., 2004), increasing uncertainty regarding species boundaries, mainly in species complexes (Cavallari et al., 2010; Costea et al., 2011, 2015; Vega et al., 2013; Marques et al., 2014). The idea that species integrity is maintained even in the presence of low levels of interspecific gene exchange has altered the concept of "complete reproductive isolation," initially postulated in the biological species concept (Mayr, 1942), to "partially permeable reproductive isolation," known as a porous genome ( $\mathrm{Wu}, 2001)$. Recent approaches have shown that a combination of multiple reproductive barriers to gene exchange act in concert, preventing the collapse of species (Palma-Silva et al., 2011; Vega et al., 2013; Marques et al., 2014; Pinheiro et al., 2016; Neri et al., 2017, 2018). Therefore, a multidisciplinary approach is crucial when studying barriers to gene exchange, which in turn will clarify the ecological and genetic mechanisms acting during species and lineage diversification. For instance, interspecific gene exchange may result in transfer of adaptive traits between closely related species, reducing extinction risks during environmental changes (Cannon and Lerdau, 2015).

It is important to highlight that speciation is a population-level process, which involves the evolution of reproductive isolation among different populations (Scopece et al., 2010). The study of reproductive barriers within species, or within species complexes, would help determine the first stages of the speciation process in situations in which species formation is still incomplete. The population-level analysis of the ecological and genetic causes of reproductive isolation was named "the magnifying glass" approach (Via, 2009). This approach is suitable for determining whether ecological and genetic mechanisms are activated before speciation is complete, avoiding confusion with the changes that accumulate after species formation. Very few studies have used this approach in tropical plants as models (but see Pinheiro et al., 2013). One potential reason for this is that most authors still interpret the biological species concept in its original version, in which reproductive isolation would be completely absent among populations within species. A change in this perception and the inclusion of "speciation in a continuum" and "speciation with gene flow" ideas (Wu, 2001; Nosil, 2012; Seehausen et al., 2014) are urgently needed to encourage investigations of reproductive barriers during the early stages of divergence: within species and/or species complexes.

Ecological data were included in 14 of the 56 studies that involved multidisciplinary approaches (Figure 6, Table 1). Eight of these studies included a range of methods, such as the analysis of single lines of environmental data including temperature and/or rainfall, or included more climatic variables to characterize the environments in which the populations were sampled. Actually, the history of species complex studies is strongly associated with characterizing the heterogeneous environments in which the populations were found (Turesson, 1922). The study of ecotypes and races stimulated the use of novel and creative approaches to disentangle the effects of different habitats on variations in morphological characters. For example, transplant experiments are crucial to understand how plasticity and/or heritable characters are responsible for the variation found among populations 
growing in divergent habitats (Clausen et al., 1939). In our survey, $38 \%$ of the studies applied morphometric analyses to investigate species complexes, indicating potential phenotypic variation within the species complexes. In the studies that employed morphometric analyses, 49 studies in total, it would help to know whether the morphological variation was caused by phenotypic plasticity, local adaptation, or both. Classical reciprocal transplant experiments are not always feasible, but alternatives, such as rearing/raising/growing divergent phenotypes in controlled climatic environments, (e.g., common garden studies) could be implemented more easily (Franks et al., 2014). Nevertheless, Esteves and Vicentini (2013) used morphometry and habitat characterization to explore the existence of plasticity and/or selection for different environments in the Pagamea coriacea Benth. complex. They found two discrete morphological groups in this complex, associated with different habitat preferences and reproductive behaviors. Turchetto et al. (2014) reported strong connections among morphological, genetic, and environmental variables, suggesting that selection for different habitats, rather than plasticity, is responsible for the diversification of lineages in the Petunia axillaris (Lam.) Britton, Sterns \& Poggenb. complex. Salinity, elevation, and climate were important environmental drivers for lineage diversification in the Hypochaeris apargioides Hook. \& Arn. complex (López-Sepúlveda et al., 2013a).

Phylogeographic studies have played a central role in interpreting how past orogenic changes and climatic fluctuations have affected the diversification of lineages and species in South America (TurchettoZolet et al., 2013; Smith et al., 2014; Leal et al., 2016b; among others). Unfortunately, in our review, only seven studies used a phylogeographic approach to evaluate species complexes (Figure 5A). For example, morphological and molecular data have been combined to study the Vellozia hirsuta Goeth.\& Henrard complex, a highly polymorphic group found among disjointed mountains within the Espinhaço Mountain Range in Brazil (Barbosa et al., 2012). Despite strong morphological differentiation among populations, no associations with the genetic lineages were found, suggesting that $V$. hirsuta should be considered a single polymorphic species. Bonatelli et al. (2014) concluded that diversification of the P. aurisetus complex has been affected by long-term isolation in microrefugia composed of xerophytic vegetation, by combining detailed demographic analyses, divergence time estimates, and niche modeling. Integrating different types of data is commonly performed in phylogeographic studies to obtain a clear picture of the processes involved in lineage and species diversification. Considering the growing number of phylogeographic studies in South America (Turchetto-Zolet et al., 2013), several groups remain poorly studied, and many questions remain unanswered. Of special interest are studies exploring how reproductive isolation evolves in a geographic context, and how selective pressures for divergent environments contribute to the formation of barriers preventing gene exchange among populations (Vallejo-Marín and Hiscock, 2016).

Phylogenetic inferences are crucial to recognize broad evolutionary relationships among lineages and species, enabling the recognition of groups that may refer to species complexes. For instance, the phylogeny published by Pinheiro et al. (2009) provided the basic framework for a detailed study of a particular group of Epidendrum showing unclear species boundaries (Pessoa et al., 2012). The same strategy is observed in other groups, such as the phylogenetic study published for the tribe Bignonieae (Bignoniaceae, Lamiales, Lohmann, 2006), allowing further population-level studies in species complexes (Firetti-Leggieri et al., 2011; Zuntini et al., 2015). One of the advantages of this approach is to identify cases of trait convergence, to avoid the study of unrelated paraphyletic groups. Rodrigues et al. (2015) constructed a phylogenetic inference for the Cattleya coccinea complex, and the recognition of different clades was important for the detailed study of Leal et al. (2016a), using morphometric and microsatellite analyses. The study performed by Welker et al. (2015) also identified several clades within the genus Saccharum, allowing future studies to explore particular microevolutionary processes within each species group of this genus. Species complexes belonging to monophyletic groups would facilitate the identification of drivers that fuel diversification events such as lineage dating (Perret et al., 2007; Breitkopf et al., 2015) and trait evolution (Silvestro et al., 2014; Lagomarsino et al., 2016).

In our review, species tree-based methods for species delimitation were limited to the application of a single or few universal markers, thus not incorporating tree-based coalescent methods. However, the accuracy of species delimitation based on a few or single gene trees may be limited and prone to incongruences due to incomplete lineage sorting, hybridization, and introgression (Naciri and Linder, 2015). Thus, unlinked loci and multispecies coalescent methods, which combine concepts from phylogenetic and population genetics, may help to overcome these difficulties. In general, the application of such methods is advantageous because they (1) are highly replicable and capable of being used by researchers in different areas (e.g., ecology, physiology, and systematics) (Flot et al., 2010); (2) are based on falsifiable hypotheses, 
removing possible biases inherent to the taxonomist (Fujita et al., 2012); (3) incorporate hypothetical species with incomplete lineage sorting and gene flow (see Camargo et al., 2012, Jackson et al., 2017 and Chan et al., 2017), and (4) have an objective statistical framework (Huang and Knowles, 2016). The study of cryptic diversity in Cerrado endemic lizards was a good example of using high-throughput phylogenomic data and coalescent techniques to delimit species and to investigate patterns of species diversity in a geographically widespread animal species (Domingos et al., 2017).

However, the application of multispecies coalescent methods solely to identify evolutionarily independent lineages to delimit species has been criticized (Freudenstein et al., 2017; Sukumaran and Knowles, 2017). Again, the thin line that distinguishes a species population at the beginning of divergence raises the question of the epistemological concept of multispecies coalescence techniques that use only molecular data, showing that this method elucidates the genetic structure, not the delimitation of the species itself (Sukumaran and Knowles, 2017), and the ecological role that a given species plays is crucial for better characterization of the taxa in question (Freudenstein et al., 2017).

Therefore, no method is a panacea, and any approach to species delimitation is unable to distinguish precisely certain taxa given the complexity of evolutionary history (Carstens et al., 2013). Species delimited in multispecies coalescent methods should be considered as hypotheses, and their delimitation should be based on the greatest possible numbers of lines of evidence and methods, as discussed above, with the aim of achieving congruence between them, resulting in a greater robustness of the $a$ priori hypothesis (Carstens et al., 2013; Chan et al., 2017; Sukumaran and Knowles, 2017). Thus, methods that incorporate different and independent data, such as ecological, phenotypic, and geographic data, with multilocus analyses and coalescence theory (e.g., iBPP-integrated Bayesian Phylogenetics and Phylogeography, Solís-Lemus et al., 2015; the Guillot model, Guillot et al., 2012) are the new frontier for studies of species complexes. In such studies, these methods may enhance the prediction of species delimitation by contributing independent datasets, seeking the congruence (or the lack thereof) of distinct hypotheses (Sukumaran and Knowles, 2017).

\section{Concluding remarks and perspectives}

Our review retrieved 129 studies that explicitly investigated species complexes in South America, which is probably very low considering the levels of plant diversity on this continent. The actual number of biological species is likely to be greater than the current list of nominal species. There is likely a long list of reasons for this, including the fact that species divergence is not always followed by morphological changes, or that morphological and/or ecological variation can occur with low genetic divergence.

Thus, multidisciplinary approaches are crucial to understanding the integrity and boundaries within species complexes (Stebbins, 1950). Integrative taxonomy has fueled discussions about strategies to combine different data sources to achieve comprehensive species delineation (Constance, 1964; Padial et al., 2010). This approach is central for planning future studies of species complexes and may help guide efforts to understand plant speciation in tropical regions. In addition, the creative use of available databases holds great promise for investigating species complexes. Inexpensive approaches, such as crossing experiments and ecological niche modeling, in addition to the data available in public databases, such as TreeBASE (for published phylogenies), GenBank (for molecular data), GBIF (for georeferenced collections), and Dryad (for alignments and morphological matrices), can be associated with multispecies coalescent data, generated from cost-effective sequencing (RADseq, GBS, exon capture, among others; Herrera and Shank, 2016), yielding unprecedented resolution of species boundaries among South American plant species complexes. Furthermore, using genome scanning methods, it is also possible to identify loci and genomic regions under adaptive divergence that may be responsible for reproductive isolation and ecological speciation among populations (Hoban et al. 2016)

We thus believe that the application of new methodologies, such as multispecies coalescence techniques, integrated with different source data (Guillot et al., 2012; Solís-Lemus et al., 2015) in species delimitation of South American species complexes will greatly improve our knowledge of the lineage diversification and speciation processes in this rich biota. In fact, the history of plant variation studies shows that investigating a species complex depends on a creative combination of diverse informative methods. In this context, species complexes should be viewed as important models to understand plant speciation and adaptation, inspiring new generations of botanists, ecologists, and evolutionary biologists.

\section{Acknowledgments}

The authors are grateful to Dr. Rafael Batista Louzada for helpful discussions regarding the evolution of species complexes. The authors also thank Mauro Peixoto for use of pictures A-D, Viviana G. Solís Neffa for use of pictures $\mathrm{E}-\mathrm{H}$, and 
Evandro Marsola de Moraes for use of pictures I-L, all included in Figure 1. Grants from Conselho Nacional de Desenvolvimento Científico e Tecnológico (CPS: CNPq-Universal 475937/2013-9, and Fellowship 300819/2016-1; FP: CNPq-Universal 440367/2014-0 and fellowship 300927/2016-9) and Fundação de Amparo à Pesquisa do Estado de São Paulo (CPS: FAPESP-2014/15588-6; FP: FAPESP 2016/22785-8) funded this study.

\section{ORCID}

Fábio Pinheiro (iD) http://orcid.org/0000-0003-3243-2652

\section{References}

Allred, K. W., and Gould, F. W. 1983. Systematics of the Bothriochloa saccharoides complex (Poaceae: Andropogoneae). Syst. Bot. 8: 168. doi:10.2307/2418692.

Alvarez, N. M. B., Peralta, I. E., Salas, A., and Spooner, D. M. 2008. A morphological study of species boundaries of the wild potato Solanum brevicaule complex: replicated field trials in Peru. Plant Syst. Evol. 274: 37-45. doi:10.1007/ s00606-008-0023-1.

Alves, T. L. S., Chauveau, O., Eggers, L., and Souza-Chies, T. T. 2014. Species discrimination in Sisyrinchium (Iridaceae): assessment of DNA barcodes in a taxonomically challenging genus. Mol. Ecol. Resour. 14: 324-335. doi:10.1111/ 1755-0998.12182.

Ames, M., Salas, A., and Spooner, D. M. 2008. A morphometric study of species boundaries of the wild potato Solanum series piurana (Solanaceae) and putatively related species from seven other series in Solanum sect. Petota. Syst. Bot. 33: 566-578. doi:10.1600/ 036364408785679789.

Ames, M., and Spooner, D. M. 2010. Phylogeny of Solanum series Piurana and related species in Solanum section Petota based on five conserved ortholog sequences. Taxon 59: 1091-1101.

Amico, G. C., and Nickrent, D. L. 2009. Population structure and phylogeography of the mistletoes Tristerix corymbosus and T. aphyllus (Loranthaceae) using chloroplast DNA sequence variation. Am. J. Bot. 96: 1571-1580. doi:10.3732/ ajb.0800302.

Andre, T. J. C., Specht, C., Salzman, S., Palma-Silva, C., and Wendt, T. 2015. Evolution of species diversity in the genus Chamaecostus (Costaceae): molecular phylogenetics and morphometric approaches. Phytotaxa 204: 265-276. doi:10.11646/phytotaxa.204.4.3.

Antonelli, A., and Sanmartín, I. 2011. Why are there so many plant species in the Neotropics? Taxon 60: 403-414.

Baack, E., Melo, M. C., Rieseberg, L. H., and Ortiz-Barrientos, D. 2015. The origins of reproductive isolation in plants. New Phytol. 207: 968-984. doi:10.1111/nph.13424.

Ballard, H. E., and Iltis, H. H. 2012. Viola lilliputana sp. nov. (Viola sect. Andinium, Violaceae), one of the world's smallest violets, from the Andes of Peru. Brittonia 64: 353-358. doi:10.1007/s12228-012-9238-0.

Barbosa, A. R., Fiorini, C. F., Silva-Pereira, V., Mello-Silva, R., and Borba, E. L. 2012. Geographical genetic structuring and phenotypic variation in the Vellozia hirsuta (Velloziaceae) ochlospecies complex. Am. J. Bot. 99: 1477-1488. doi:10.3732/ajb.1200070.

Barley, A. J., White, J., Diesmos, A. C., and Brown, R. M. 2013. The challenge of species delimitation at the extremes: diversification without morphological change in Philippine sun skinks. Evolution 67: 3556-3572. doi:10.1111/evo.12219.

Barthlott, W., Mutke, J., Rafiqpoor, D., Kier, G., and Kreft, H. 2005. Global centers of vascular plant diversity. Nov. Acta Leopoldina 92: 61-83.

Bastian, M., Heymann, S., and Jacomy, M. 2009. Gephi: an open source software for exploring and manipulating networks. Third Int. AAAI Conf. Weblogs Soc. Media. 361-362.

Berg, R. G. van den, Miller, J. T., Ugarte, M. L., Kardolus, J. P., Villand, J., Nienhuis, J., and Spooner, D. M. 1998. Collapse of morphological species in the wild potato Solanum brevicaule complex (Solanaceae: Sect. Petota). Am. J. Bot. 85 92-109. doi:10.2307/2446559.

Bickford, D., Lohman, D. J., Sodhi, N. S., Ng, P. K. L., Meier, R., Winker, K., Ingram, K. K., and Das, I. 2007. Cryptic species as a window on diversity and conservation. Trends Ecol. Evol. 22: 148-155. doi:10.1016/j.tree.2006.11.004.

Blaxter, M. L. 2004. The promise of a DNA taxonomy. Philos. Trans. R. Soc. B Biol. Sci. 359: 669-679. doi:10.1098/ rstb.2003.1447.

Bonatelli, I. S., Perez, M. F., Peterson, A. T., Taylor, N. P., Zappi, D. C., Machado, M. C., Koch, I., Pires, A. H. C., and Moraes, E. M. 2014. Interglacial microrefugia and diversification of a cactus species complex: Phylogeography and palaeodistributional reconstructions for Pilosocereus aurisetus and allies. Mol. Ecol. 23: 3044-3063. doi:10.1111/ mec. 12780 .

Borba, E. L., Shepherd, G. J., Berg, C., and Semir, J. 2002. Floral and vegetative morphometrics of five Pleurothallis (Orchidaceae) species: correlation with taxonomy, phylogeny, genetic variability and pollination systems. Ann. Bot. 90: 219-230. doi:10.1093/aob/mcf168.

Borba, E. L., Barbosa, A. R., Melo, M. C., Gontijo, S. L., and Oliveira, H. O. 2011. Mating systems in the Pleurothallidinae (Orchidaceae): evolutionary and systematic implications. Lankesteriana 11: 207-221.

Borges, L. A., Souza, L. G. R., Guerra, M., Machado, I. C., Lewis, G. P., and Lopes, A. V. 2012. Reproductive isolation between diploid and tetraploid cytotypes of Libidibia ferrea ( = Caesalpinia ferrea) (Leguminosae): Ecological and taxonomic implications. Plant Syst. Evol. 298: 1371-1381. doi:10.1007/s00606-012-0643-3.

Borsch, T., Limarino, T. O., and Nee, M. H. 2011. Phylogenetics of the neotropical liana genus Pedersenia (Amaranthaceae: Gomphrenoideae) and discovery of a new species from Bolivia based on molecules and morphology. Willdenowia 41: 5-14. doi:10.3372/wi.41.41101.

Breitkopf, H., Onstein, R. E., Cafasso, D., Schlüter, P. M., and Cozzolino, S. 2015. Multiple shifts to different pollinators fuelled rapid diversification in sexually deceptive Ophrys orchids. New Phytol. 207: 377-389. doi:10.1111/ nph.13219.

Briggs, D., and Walters, S. 1997. Plant Variation and Evolution. Cambridge University Press, Cambridge.

Bünger, M. O., Einsehlor, P., Figueiredo, M. L. N., and Stehmann, J. R. 2015. Resolving species delimitations in the Eugenia involucrata group (Eugenia sect. Phyllocalyx - 
Myrtaceae) with morphometric analysis. Syst. Bot. 40: 9951002. doi:10.1600/036364415X690030.

Caddah, M. K., Mayer, J. L. S., Bittrich, V., and Amaral, M. C. E. 2012. Species limits in the Kielmeyera coriacea complex (Calophyllaceae) - a multidisciplinary approach. Bot. J. Linn. Soc. 168: 101-115. doi:10.1111/j.10958339.2011.01192.x.

Caddah, M. K., Campos, T., Zucchi, M. I., Souza, A. P. de, Bittrich, V., and Amaral, M. C. E. do. 2013. Species boundaries inferred from microsatellite markers in the Kielmeyera coriacea complex (Calophyllaceae) and evidence of asymmetric hybridization. Plant Syst. Evol. 299: 731-741. doi:10.1007/ s00606-012-0755-9.

Caetano, S., Nusbaumer, L., and Naciri, Y. 2008. Chloroplast and microsatellite markers in Astronium urundeuva (Allemão) Engl. and close species of Anacardiaceae: toward the definition of a species complex? Candollea 63: 115-130.

Camargo, A., Morando, M., Avila, L. J., and Sites, J. W. 2012. Species delimitation with ABC and other coalescent-based methods: a test of accuracy with simulations and an empirical example with lizards of the Liolaemus darwinii complex (Squamata: Liolaemidae). Evolution (N. Y). 66: 2834-2849.

Canela, M. B. F., Prado-Lopez, N. P., and Wendt, T. 2003. Revision of the Aechmea multiflora complex (Bromeliaceae). Bot. J. Linn. Soc. 143: 189-196. doi:10.1046/j.10958339.2003.00202.x.

Cannon, C. H., and Lerdau, M. 2015. Variable mating behaviors and the maintenance of tropical biodiversity. Front. Genet. 6: 183. doi:10.3389/fgene.2015.00183.

Cardim, D. C., Carlini-Garcia, L. A., Mondin, M., Martins, M., Veasey, E. A., and Ando, A. 2001. Variabilidade intraespecífica em cinco populações de Oncidium varicosum Lindl. (Orchidaceae - Oncidiinae) em Minas Gerais. Rev. Bras. Botânica 24: 553-560. doi:10.1590/S010084042001000500010.

Cardozo, A. P., Godinho-Temponi, L., Moreira de Andrade, I., Mayo, S. J., and Smidt, E. C. 2015. A morphometric and taxonomic study of Anthurium augustinum complex (Araceae), endemic to the Brazilian Atlantic Forest. Feddes Repert. 125: 43-58. doi:10.1002/fedr.201400025.

Carlini-Garcia, L. A., Berg, C. van den, and Martins, P. S. 2002. A morphometric analysis of floral characters in Miltonia spectabilis and Miltonia spectabilis var. moreliana (Maxillarieae: Oncidiinae). Lindleyana 17: 122-129.

Carstens, B. C., Pelletier, T. A., Reid, N. M., and Satler, J. D. 2013. How to fail at species delimitation. Mol. Ecol. 22: 4369-4383. doi:10.1111/mec.12413.

Carstens, B. C., and Satler, J. D. 2013. The carnivorous plant described as Sarracenia alata contains two cryptic species. Biol. J. Linn. Soc. 109: 737-746. doi:10.1111/bij.12093.

Catling, P. M., and Porebski, S. 1998. A morphometric evaluation of the subspecies of Fragaria chiloensis. Can. J. Bot. 76: 290-297.

Cavallari, M. M., Gimenes, M. A., Billot, C., Torres, R. B., Zucchi, M. I., Cavalheiro, A. J., and Bouvet, J. M. 2010. Population genetic relationships between Casearia sylvestris (Salicaceae) varieties occurring sympatrically and allopatrically in different ecosystems in southeast Brazil. Ann. Bot. 106: 627-636. doi:10.1093/aob/mcq151.

Ceolin, G. B., and Miotto, S. T. S. 2012. Combining ecological and morphometrical approaches to increase the resolution within the Galactia neesii (Leguminosae) complex. Plant Syst. Evol. 298: 645-652. doi:10.1007/s00606-011-0573-5.

Chan, K. O., Alexander, A. M., Grismer, L. L., Su, Y. C., Grismer, J. L., Quah, E. S. H., and Brown, R. M. 2017. Species delimitation with gene flow: a methodological comparison and population genomics approach to elucidate cryptic species boundaries in Malaysian Torrent Frogs. Mol. Ecol. 26: 5435-5450. doi:10.1111/mec.14296.

Clausen, J., Keck, D. D., and Hiesey, W. M. 1939. The concept of species based on experiment. Am. J. Bot. 26: 103. doi:10.1002/j.1537-2197.1939.tb12875.x.

Conceição, A. S., Queiroz, L. P., Lambert, S. M., Pereira, A. C. S., and Borba, E. L. 2008. Biosystematics of Chamaecrista sect. Absus subsect. Baseophyllum (Leguminosae-Caesalpinioideae) based on allozyme and morphometric analyses. Plant Syst. Evol. 270: 183-207. doi:10.1007/s00606-0070604-4.

Constance, L. 1964. Systematic Botany - an unending synthesis. Taxon 13: 257-273. doi:10.2307/1216193.

Cooley, A. M., Carvallo, G., and Willis, J. H. 2008. Is floral diversification associated with pollinator divergence? Flower shape, flower colour and pollinator preference in Chilean Mimulus. Ann. Bot. 101: 641-650. doi:10.1093/ $\mathrm{aob} / \mathrm{mcn} 014$.

Costa, C. B. N., Lambert, S. M., Borba, E. L., and Queiroz, L. P. de. 2007. Post-zygotic reproductive isolation between sympatric taxa in the Chamaecrista desvauxii complex (Leguminosae-Caesalpinioideae). Ann. Bot. 99: 625-635. doi:10.1093/aob/mcm012.

Costa, A. F. da, Rodrigues, P. J. F. P., and Wanderley, M. G. L. 2009. Morphometric analysis and taxonomic revision of the Vriesea paraibica complex (Bromeliaceae). Bot. J. Linn. Soc. 159: 163181. doi:10.1111/j.1095-8339.2008.00919.x.

Costea, M., and Stefanović, S. 2010. Evolutionary history and taxonomy of the Cuscuta umbellata complex (Convolvulaceae): evidence of extensive hybridization from discordant nuclear and plastid phylogenies. Taxon 59: 1783-1800.

Costea, M., Ruiz, I. G., and Stefanović, S. 2011. Systematics of "horned" dodders: phylogenetic relationships, taxonomy, and two new species within the Cuscuta chapalana complex (Convolvulaceae). Botany 89: 715-730. doi:10.1139/b11049.

Costea, M., García, M. A., Baute, K., and Stefanović, S. 2015. Entangled evolutionary history of Cuscuta pentagona clade: A story involving hybridization and Darwin in the Galapagos. Taxon 64: 1225-1242. doi:10.12705/646.7.

Coyne, J., and Orr, H. 2004. Speciation. Sinauer Associates, Inc, Sunderland, MA.

Crawford, D. J. 2010. Progenitor-derivative species pairs and plant speciation. Taxon 59: 1413-1423.

Darwin, C. 1882. The Various Contrivances by Which Orchids are Fertilised by Insects. J. Murray, London.

de Queiroz, K. 1998. The general lineage concept of species, species criteria, and the process of speciation: a conceptual unification and terminological recommendations. In: Howard, D. J., and S. H. Berlocher, Eds., Endless Forms: Species and Speciation. Oxford University Press, New York: pp. 57-75.

de Queiroz, K. 2007. Species concepts and species delimitation. Syst. Biol. 56: 879-886. doi:10.1080/10635150701701083.

Dematteis, M. 2004. Taxonomía del complejo Vernonia rubricaulis (Vernonieae, Asteraceae). Bonplandia 13: 5-13. 
Díaz, D. M. V. 2013. Multivariate analysis of morphological and anatomical characters of Calophyllum (Calophyllaceae) in South America. Bot. J. Linn. Soc. 171: 587-626. doi:10.1111/boj.12012.

Diaz, J., Schmiediche, P., and Austin, D. F. 1996. Polygon of crossability between eleven species of Ipomoea: section Batatas (Convolvulaceae). Euphytica 88: 189-200. doi:10.1007/BF00023890.

Dobzhansky, T. 1937. Genetics and the Origin of Species. Columbia University Press, New York.

Domingos, F. M. C. B., Colli, G. R., Lemmon, A., Lemmon, E. M., and Beheregaray, L. B. 2017. In the shadows: phylogenomics and coalescent species delimitation unveil cryptic diversity in a Cerrado endemic lizard (Squamata: Tropidurus). Mol. Phylogenet. Evol. 107: 455-465. doi:10.1016/j. ympev.2016.12.009.

Duminil, J., Caron, H., Scotti, I., Cazal, S. O., and Petit, R. J. 2006. Blind population genetics survey of tropical rainforest trees. Mol. Ecol. 15: 3505-3513. doi:10.1111/j.1365294X.2006.03040.x.

Elías, G., Sartor, M., and Solís-Neffa, V. G. 2011. Patterns of cytotype variation of Turnera sidoides subsp. pinnatifida (Turneraceae) in mountain ranges of central Argentina. J. Plant Res. 124: 25-34. doi:10.1007/s10265-010-0347-0.

Ence, D. D., and Carstens, B. C. 2011. SpedeSTEM: A rapid and accurate method for species delimitation. Mol. Ecol. Resour. 11: 473-480. doi:10.1111/j.1755-0998.2010.02947.x.

Esteves, S. M., and Vicentini, A. 2013. Cryptic species in Pagamea coriacea sensu lato (Rubiaceae): evidence from morphology, ecology and reproductive behavior in a sympatric context. Acta Amaz. 43: 415-428. doi:10.1590/S004459672013000400003.

Farinaccio, M. A., and Mello-Silva, R. 2006. Oxypetalum gyrophyllum and O. oblanceolatum, new species of Asclepiadoideae (Apocynaceae) from Brazil, and a key for the $O$. insigne group. Novon 16: 235-239. doi:10.3417/1055-3177 (2006)16\%5b235:OGAOON\%5d2.0.CO;2.

Ferreyra, L. I., Vilardi, J. C., Verga, A., López, V., and Saidman, B. O. 2013. Genetic and morphometric markers are able to differentiate three morphotypes belonging to Section Algarobia of genus Prosopis (Leguminosae, Mimosoideae). Plant Syst. Evol. 299: 1157-1173. doi:10.1007/s00606-013-0786-x.

Filardi, F. L. R., Lima, H. C. de, Klitgaard, B. B., and Sartori, Â. L. B. 2013. Taxonomy and nomenclature of the neotropical Machaerium hirtum complex (Leguminosae, Papilionoideae). Brittonia 65: 154-170. doi:10.1007/s12228-012-9276-7.

Firetti-Leggieri, F., Ribeiro da Costa, I., Lohmann, L. G., Semir, J., and Forni-Martins, E. R. 2011. Chromosome studies in Bignonieae (Bignoniaceae): the first record of polyploidy in Anemopaegma. Cytologia 76: 185-191. doi:10.1508/ cytologia.76.185.

Flot, J. F., Couloux, A., and Tillier, S. 2010. Haplowebs as a graphical tool for delimiting species: a revival of Doyle's "field for recombination" approach and its application to the coral genus Pocillopora in Clipperton. BMC Evol. Biol. 10: 372. doi:10.1186/1471-2148-10-372.

Flot, J. F. 2015. Species delimitation's coming of age. Syst. Biol. 64: 897-899. doi:10.1093/sysbio/syv071.

Folk, R. A., and Freudenstein, J. V. 2015. "Sky islands" in the eastern U.S.A.? - Strong phylogenetic structure in the Heuchera parviflora group (Saxifragaceae). Taxon 64: 254-271. doi:10.12705/642.3.
Forzza, R. C., Baumgratz, J. F. A., Bicudo, C. E. M., Canhos, D. A. L., Carvalho, A. A., Coelho, M. A. N., Costa, A. F., Costa, D. P., Hopkins, M. G., Leitman, P. M., Lohmann, L. G., Lughadha, E. N., Maia, L. C., Martinelli, G., Menezes, M., Morim, M. P., Peixoto, A. L., Pirani, J. R., Prado, J., Queiroz, L. P., Souza, S., Souza, V. C., Stehmann, J. R., Sylvestre, L. S., Walter, B. M. T., Zappi, D. C. 2012. New Brazilian floristic list highlights conservation challenges. Bioscience 62: 3945. doi:10.1525/bio.2012.62.1.8.

Franks, S. J., Weber, J. J., and Aitken, S. N. 2014. Evolutionary and plastic responses to climate change in terrestrial plant populations. Evol. Appl. 7: 123-139. doi:10.1111/eva.12112.

Freitas-Mansano, V., and Azevedo-Tozzi, A. M. G. 2001. Swartzia Schreb. (Leguminosae: Papilionoideae: Swartzieae): a taxonomic study of the Swartzia acutifolia complex including a new name and a new species from Southeastern Brazil. Kew Bull. 56: 917. doi:10.2307/4119303.

Freudenstein, J. V., Broe, M. B., Folk, R. A., and Sinn, B. T. 2017. Biodiversity and the species concept - lineages are not enough. Syst. Biol. 66: 644-656.

Fujita, M. K., Leaché, A. D., Burbrink, F. T., McGuire, J. A., and Moritz, C. 2012. Coalescent-based species delimitation in an integrative taxonomy. Trends Ecol. Evol. 27: 480-488. doi:10.1016/j.tree.2012.04.012.

Gagnon, E., Hughes, C. E., Lewis, G. P., and Bruneau, A. 2015. A new cryptic species in a new cryptic genus in the Caesalpinia group (Leguminosae) from the seasonally dry interAndean valleys of South America. Taxon 64: 468-490. doi:10.12705/643.6.

Gentry, A. H. 1981. Distributional patterns and an additional species of the Passiflora vitifolia complex: Amazonian species diversity due to edaphically differentiated communities. Plant Syst. Evol. 137: 95-105. doi:10.1007/ BF00983208.

Giussani, L. M., Martinez, A. J., and Collantes, M. B. 1996. Morphological variation associated with the environment in four dioecious Patagonian Poa species: the Poa rigidifolia complex. Can. J. Bot. 772: 762-772. doi:10.1139/b96-095.

Gomes-da-Silva, J., and da Costa, A. F. 2011. A taxonomic revision of Vriesea corcovadensis group (Bromeliaceae: Tillandsioideae) with description of two new species. Syst. Bot. 36 291-309. doi:10.1600/036364411X569499.

Gomes-da-Silva, J., Vargens, F. A. C., Arruda, R. C. O., and da Costa, A. F. 2012. A morphological cladistic analysis of the Vriesea corcovadensis group (Bromeliaceae: Tillandsiodeae), with anatomical descriptions: new evidence of the nonmonophyly of the genus. Syst. Bot. 37: 641-654. doi:10.1600/036364412X648599.

Gonella, P. M., Rivadavia, F., and Sano, P. T. 2012. Re-establishment of Drosera spiralis (Droseraceae), and a new circumscription of D. graminifolia. Phytotaxa 75: 43-57. doi:10.11646/phytotaxa.75.1.4.

Gonella, P. M., Rivadavia, F., Sano, P. T., and Fleischmann, A. 2014. Exhuming Saint-Hilaire: revision of the Drosera villosa complex (Droseraceae) supports 200 year-old neglected species concepts. Phytotaxa 156: 1-40. doi:10.11646/ phytotaxa.156.1.1.

Govaerts, R. 2001. How many species of seed plants are there? Taxon 50: 1085-1090. doi:10.2307/1224723.

Graham, S. A., and Cavalcanti, T. B. 2013. Taxonomic revision of Cuphea sect. Euandra subsect. Oidemation (Lythraceae). Phytotaxa 113: 1-86. doi:10.11646/phytotaxa.113.1.1. 
Grombone-Guaratini, M. T., Semir, J., and Solferini, V. N. 2005. Low allozymic variation in the Bidens pilosa L. complex (Asteraceae). Biochem. Genet. 43: 335-345. doi:10.1007/s10528-005-6774-2.

Grombone-Guaratini, M. T., Solferini, V. N., Mansanares, M. E., and Semir, J. 2006. Chromosomal studies of three species of Bidens L. (Asteraceae). Caryologia 59: 14-18. doi:10.1080/00087114.2006.10797892.

Guillot, G., Renaud, S., Ledevin, R., Michaux, J., and Claude, J. 2012. A unifying model for the analysis of phenotypic, genetic, and geographic data. Syst. Biol. 61: 897-911. doi:10.1093/sysbio/sys038.

Hagen, J. B. 1984. Experimentalists and naturalists in twentieth-century botany: experimental taxonomy, 1920-1950. J. Hist. Biol. 17: 249-270. doi:10.1007/BF00143734.

Hausdorf, B. 2011. Progress toward a general species concept. Evolution 65: 923-931. doi:10.1111/j.1558-5646.2011.01231.x.

Heath, T. A., Hedtke, S. M., and Hillis, D. M. 2008. Taxon sampling and the accuracy of phylogenetic analyses. J. Syst. Evol. 46: 239-257.

Heled, J., and Drummond, A. J. 2010. Bayesian inference of species trees from multilocus data. Mol. Biol. Evol. 27: 570580. doi:10.1093/molbev/msp274.

Henderson, A., and Martins, R. 2002. Classification of specimens in the Geonoma stricta (Palmae) complex: the problem of leaf size and shape. Brittonia 54: 202-212. doi:10.1663/0007-196X(2002)054\%5b0202: COSITG\%5d2.0.CO;2.

Hennig, W. 1966. Phylogenetic Systematics. University of Illinois Press, Urbana.

Herrera, S., and Shank, T. M. 2016. RAD sequencing enables unprecedented phylogenetic resolution and objective species delimitation in recalcitrant divergent taxa. Mol. Phylogenet. Evol. 100: 70-79. doi:10.1016/j.ympev.2016.03.010.

Hoban, S., Kelley, J. L., Lotterhos, K. E., Antolin, M. F., Bradburd, G., Lowry, D. B., Poss, M. L., Reed, L. K., Storfer, A., and Whitlock, M. C. 2016. Finding the genomic basis of local adaptation: pitfalls, practical solutions, and future directions. Am. Nat. 188: 379-397. doi:10.1086/688018.

Holanda, A. S. S. de, Vicentini, A., Hopkins, M. J. G., and Zartman, C. E. 2015. Phenotypic differences are not explained by pre-zygotic reproductive barriers in sympatric varieties of the Humiria balsamifera complex (Humiriaceae). Plant Syst. Evol. 301: 1767-1779. doi:10.1007/s00606-014-1191-9.

Huang, J. P., and Knowles, L. L. 2016. The species versus subspecies conundrum: quantitative delimitation from integrating multiple data types within a single Bayesian approach in hercules beetles. Syst. Biol. 65: 685-699. doi:10.1093/sysbio/syv119.

haHughes, C. E., Pennington, R. T., and Antonelli, A. 2013. Neotropical plant evolution: assembling the big picture. Bot. J. Linn. Soc. 171: 1-18. doi:10.1111/boj.12006.

Ispizúa, V. N., Camadro, E. L., and Clausen, A. M. 2015. Variation patterns in natural populations of wild potatoes along Quebrada de Inca Cueva, Northwestern Argentina. Genet. Resour. Crop Evol. 62: 235-253. doi:10.1007/s10722-0140149-7.

Jackson, N. D., Morales, A. E., Carstens, B. C., and O’Meara, B. C. 2017. PHRAPL: phylogeographic inference using approximate likelihoods. Syst. Biol. 66: 1045-1053. doi:10.1093/sysbio/syx001.
Jones, G., Aydin, Z., and Oxelman, B. 2015. DISSECT: An assignment-free Bayesian discovery method for species delimitation under the multispecies coalescent. Bioinformatics 31: 991-998. doi:10.1093/bioinformatics/btu770.

Kingman, J. F. C. 1982. The coalescent. Stoch. Process. Their Appl. 13: 235-248. doi:10.1016/0304-4149(82)90011-4.

Knowles, L. L., and Carstens, B. C. 2007. Delimiting species without monophyletic gene trees. Syst. Biol. 56: 887-895. doi:10.1080/10635150701701091.

Lagomarsino, L. P., Condamine, F. L., Antonelli, A., Mulch, A., and Davis, C. C. 2016. The abiotic and biotic drivers of rapid diversification in Andean bellflowers (Campanulaceae). New Phytol. 210: 1430-1442. doi:10.1111/nph.13920.

Lammers, T. G., and Hensold, N. 1992. Chromosome numbers of Campanulaceae II. The Lobelia-Tupa complex of Chile. Am. J. Bot. 79: 585-588. doi:10.1002/j.1537-2197.1992. tb14596.x.

Leal, B. S. S., Chaves, C. J. N., Koehler, S., and Borba, E. L. 2016a. When hybrids are not hybrids: a case study of a putative hybrid zone between Cattleya coccinea and C. brevipedunculata (Orchidaceae). Bot. J. Linn. Soc. 181: 621639. doi:10.1111/boj.12437.

Leal, B. S. S., Palma-Silva, C., and Pinheiro, F. 2016b. Phylogeographic studies depict the role of space and time scales of plant speciation in a highly diverse neotropical region. Crit. Rev. Plant Sci. 35: 215-230. doi:10.1080/ 07352689.2016.1254494.

Levin, D. A. 1978. The origin of isolating mechanisms in flowering plants. In: Evolutionary Biology. Springer US, Boston, MA. pp. 185-317.

Lima, D. F., Mauad, A. V. S., Silva-Pereira, V., Smidt, E. C., and Goldenberg, R. 2015. Species boundaries inferred from ISSR markers in the Myrcia laruotteana complex (Myrtaceae). Plant Syst. Evol. 301: 353-363. doi:10.1007/s00606-0141078-9.

Lipscomb, D., Platnick, N., and Wheeler, Q. 2003. The intellectual content of taxonomy: a comment on DNA taxonomy. Trends Ecol. Evol. 18: 65-66. doi:10.1016/S0169-5347(02)00060-5.

Lohmann, L. G. 2006. Untangling the phylogeny of neotropical lianas (Bignonieae, Bignoniaceae). Am. J. Bot. 93: 304-318. doi:10.3732/ajb.93.2.304.

Lombardi, J. A. 2006. A new species of Tontelea from Amazonian Peru and Ecuador, and notes on the Tontelea attenuata species group (Celastraceae, Hippocrateoideae). Brittonia 58: 52-58. doi:10.1663/0007-196X(2006) 58\%5b52:ANSOTF\%5d2.0.CO;2.

Longo, D., Lorenz-Lemke, A. P., Mäder, G., Bonatto, S. L., and Freitas, L. B. 2014. Phylogeography of the Petunia integrifolia complex in Southern Brazil. Bot. J. Linn. Soc. 174: 199213. doi:10.1111/boj.12115.

López-Sepúlveda, P., Tremetsberger, K., Ortiz, M. Á., Baeza, C. M., Peñailillo, P., and Stuessy, T. F. 2013a. Radiation of the Hypochaeris apargioides complex (Asteraceae: Cichorieae) of southern South America. Taxon 62: 550-564. doi:10.12705/623.14.

López-Sepúlveda, P., Takayama, K., Greimler, J., Peñailillo, P., Crawford, D. J., Baeza, M., Ruiz, E., Kohl, G., Tremetsberger, K., Gatica, A., Letelier, L., Novoa, P., Novak, J., and Stuessy, T. F. 2013b. Genetic variation (Aflps and nuclear microsatellites) in two anagenetically derived endemic species of myrceugenia (Myrtaceae) on the juan fernández 
Islands, Chile. Am. J. Bot. 100: 722-734. doi:10.3732/ ajb.1200541.

López-Sepúlveda, P., Takayama, K., Greimler, J., Crawford, D. J., Peñailillo, P., Baeza, M., Ruiz, E., Kohl, G., Tremetsberger, K., Gatica, A., Letelier, L., Novoa, P., Novak, J., and Stuessy, T. F. 2015a. Speciation and Biogeography of Erigeron (Asteraceae) in the Juan Fernández Archipelago, Chile, based on AFLPs and SSRs. Syst. Bot. 40: 888-899. doi:10.1600/036364415X689311.

López-Sepúlveda, P., Takayama, K., Greimler, J., Crawford, D. J., Peñailillo, P., Baeza, M., Ruiz, E., Kohl, G., Tremetsberger, K., Gatica, A., Letelier, L., Novoa, P., Novak, J., and Stuessy, T. F. 2015b. Progressive migration and anagenesis in Drimys confertifolia of the Juan Fernández Archipelago, Chile. J. Plant Res. 128: 73-90. doi:10.1007/s10265-0140666-7.

López, M. G., Wulff, A. F., Wulff, A. F., Xifreda, C. C., and Xifreda, C. C. 2002. Chromosome contribution to Andean polyploid species of Senecio (Asteraceae), from Argentina. Caryologia 55: 27-35. doi:10.1080/ 00087114.2002 .10589255$.

López, P., Tremetsberger, K., Kohl, G., and Stuessy, T. 2012. Progenitor-derivative speciation in Pozoa (Apiaceae, Azorelloideae) of the southern Andes. Ann. Bot. 109: 351-363. doi:10.1093/aob/mcr291.

Lousada, J. M., Lovato, M. B., and Borba, E. L. 2013. High genetic divergence and low genetic variability in disjunct populations of the endemic Vellozia compacta (Velloziaceae) occurring in two edaphic environments of Brazilian campos rupestres. Rev. Bras. Bot. 36: 45-53. doi:10.1007/ s40415-013-0001-x.

Luckow, M., and Hortorium, L. H. B. 1995. Species concepts: assumptions, methods, and applications. Syst. Bot. 20: 589605. doi:10.2307/2419812.

Marques, I., Draper, D., Riofrío, L., and Naranjo, C. 2014. Multiple hybridization events, polyploidy and low postmating isolation entangle the evolution of neotropical species of Epidendrum (Orchidaceae). BMC Evol. Biol. 14: 20. doi:10.1186/1471-2148-14-20.

Marquete, R., and Mansano, V. F. 2012. Taxonomic rrevision of the Casearia ulmifolia complex (Salicaceae). Novon 22: 196-206. doi:10.3417/2011011.

Mayden, R. L. 1997. A hierarchy of species concepts: the denouement in the saga of the species problem. In: Claridge, M. F., H. A. Dawah, and M. R. Wilson, Eds., Species: the Units of Biodiversity. Chapman and Hall, London. pp. 381-424.

Mayr, E. 1942. Systematics and the Origin of Species. Columbia University Press, New York.

Melo, M. C., and Borba, E. L. 2011. Morphological variability in rupicolous species of the Acianthera prolifera complex (Orchidaceae) occurring in Southeastern Brazil. Plant Syst. Evol. 293: 135-145. doi:10.1007/s00606-011-0435-1.

Meneguzzo, T. E. C., Baumgratz, J. F. A., and Berg, C. van den. 2015. Taxonomic studies in the Aganisia complex (Orchidaceae, Zygopetalinae). Phytotaxa 238: 1. doi:10.11646/ phytotaxa.238.1.1.

Miller, J. T., and Spooner, D. M. 1999. Collapse of species boundaries in the wild potato Solanum brevicaule complex (Solanaceae, S. sect. Petota): molecular data. Plant Syst. Evol. 214: 103-130. doi:10.1007/BF00985734.
Miz, R. B., Mentz, L. A., and Souza-Chies, T. T. 2008. Overview of the phylogenetic relationships of some southern Brazilian species from section Torva and related sections of "spiny Solanum" (Solanum subgenus Leptostemonum, Solanaceae). Genetica 132: 143-158. doi:10.1007/s10709-007-9156-3.

Moraes, E. M., Perez, M. F., Téo, M. F., Zappi, D. C., Taylor, N. P., and Machado, M. C. 2012. Cross-species amplification of microsatellites reveals incongruence in the molecular variation and taxonomic limits of the Pilosocereus aurisetus group (Cactaceae). Genetica 140: 277-285. doi:10.1007/ s10709-012-9678-1.

Morales, A. E., and Carstens, B. C. 2018. Evidence that Myotis lucifugus "subspecies" are five non-sister species, despite gene flow. Syst. Biol. Ahead of print: 1-14.

Moreno, E. M. S., Speranza, P. R., Roggero-Luque, J. M., and Solís-Neffa, V. G. 2015. Natural hybridization among subspecies of Turnera sidoides L. (Passifloraceae) revealed by morphological and genetic evidence. Plant Syst. Evol. 301: 883-892. doi:10.1007/s00606-014-1122-9.

Naciri, Y., and Linder, H. P. 2015. Species delimitation and relationships: the dance of the seven veils. Taxon 64: 3-16. doi:10.12705/641.24.

Neri, J., Wendt, T., Leles, B., Santos, M. F., and PalmaSilva, C. 2017. Variation in reproductive systems facilitates species boundaries of sympatric Vriesea (Bromeliaceae). Bot. J. Linn. Soc. 184: 272-279. doi:10.1093/ botlinnean/box026.

Neri, J., Wendt, T., and Palma-Silva, C. 2018. Natural hybridization and genetic and morphological variation between two epiphytic bromeliads. AoB Plants 10: plx061. doi:10.1093/aobpla/plx061.

Norrmann, G. A. 2009. Natural hybridization in the Andropogon lateralis complex (Andropogoneae, Poaceae) and its impact on taxonomic literature. Bot. J. Linn. Soc. 159: 136154. doi:10.1111/j.1095-8339.2008.00904.x.

Nosil, P. 2008. Speciation with gene flow could be common. Mol. Ecol. 17: 2103-2106. doi:10.1111/j.1365294X.2008.03715.x.

Nosil, P. 2012. Ecological Speciation. Oxford University Press, Oxford.

O’Leary, N., Denham, S. S., Salimena, F., and Múlgura, M. E. 2012. Species delimitation in Lippia section Goniostachyum (Verbenaceae) using the phylogenetic species concept. Bot. J. Linn. Soc. 170: 197-219. doi:10.1111/j.10958339.2012.01291.x.

O’Meara, B. C. 2010. New heuristic methods for joint species delimitation and species tree inference. Syst. Biol. 59: 5973. doi:10.1093/sysbio/syp077.

Oliveira, M. I. U., Landrum, L. R., Oliveira, R. P., and Funch, L. S. 2013. A new species of Campomanesia (Myrtaceae) from Bahia, Brazil, and its relationships with the C. xanthocarpa complex. Phytotaxa 149: 19-26. doi:10.11646/ phytotaxa.149.1.3.

Oliveira, R. C., and Valls, J. F. M. 2002. Taxonomia de Paspalum L., grupo Linearia (Gramineae - Paniceae) do Brasil. Rev. Bras. Botânica 25: 371-389. doi:10.1590/S010084042002012000001.

Oliveira, R. C. de, Valls, J. F. M., Gomes, S. M., Fagg, C. W., and Toniolo Pozzobon, M. 2015. A new species of Paspalum, Notata group (Poaceae, Paspaleae), from the Cerrado biome, Brazil: description, chromosome number, and leaf 
blade anatomy. Phytotaxa 203: 159-168. doi:10.11646/ phytotaxa.203.2.5.

Oliveira, R. P., Borba, E. L., Longhi-Wagner, H. M., Pereira, A. C. S., and Lambert, S. M. 2008a. Genetic and morphological variability in the Raddia brasiliensis complex (Poaceae: Bambusoideae). Plant Syst. Evol. 274: 25-35. doi:10.1007/ s00606-008-0034-y.

Oliveira, R. P., Borba, E. L., and Longhi-Wagner, H. M. 2008b. Morphometrics of herbaceous bamboos of the Raddia brasiliensis complex (Poaceae - Bambusoideae): implications for the taxonomy of the genus and new species from Brazil. Plant Syst. Evol. 270: 159-182. doi:10.1007/s00606-0070614-2.

Oliveira, V. M., Forni-Martins, E. R., and Semir, J. 2007. Cytotaxonomy of species of Vernonia, section Lepidaploa, group Axilliflorae (Asteraceae, Vernonieae). Bot. J. Linn. Soc. 154: 99-108. doi:10.1111/j.1095-8339.2007.00633.x.

Padial, J. M., and de la Riva, I. 2010. A response to recent proposals for integrative taxonomy. Biol. J. Linn. Soc. 101: 747-756. doi:10.1111/j.1095-8312.2010.01528.x.

Padial, J. M., Miralles, A., de la Riva, I., and Vences, M. 2010. The integrative future of taxonomy. Front. Zool. 7: 1-14. doi:10.1186/1742-9994-7-16.

Palacios, R. A., Burghardt, A. D., Frías-Hernández, J. T., Olalde-Portugal, V., Grados, N., Alban, L., and Martínez-de la Vega, O. 2012. Comparative study (AFLP and morphology) of three species of Prosopis of the Section Algarobia: $P$. juliflora, $P$. pallida, and $P$. limensis. Evidence for resolution of the "P. pallida-P. juliflora complex." Plant Syst. Evol. 298: 165-171. doi:10.1007/s00606-011-0535-y.

Palma-Silva, C., Wendt, T., Pinheiro, F., Barbará, T., Fay, M. F., Cozzolino, S., and Lexer, C. 2011. Sympatric bromeliad species (Pitcairnia spp.) facilitate tests of mechanisms involved in species cohesion and reproductive isolation in Neotropical inselbergs. Mol. Ecol. 20: 3185-3201. doi:10.1111/ j.1365-294X.2011.05143.x.

Palma-Silva, C., Cozzolino, S., Paggi, G. M., Lexer, C., and Wendt, T. 2015. Mating system variation and assortative mating of sympatric bromeliads (Pitcairnia spp.) endemic to neotropical inselbergs. Am. J. Bot. 102: 758-764. doi:10.3732/ajb.1400513.

Paula-Souza, J., Pirani, J. R., and Feliciano, C. D. 2011. Taxonomic and geographic notes on the Hybanthus lanatus (A. St.-Hil.) Baill. complex (Violaceae). Candollea 66: 367-375. doi:10.15553/c2011v662a14.

Pelegrin, C. M. G. de, Longhi-Wagner, H. M., and Oliveira, P. L. 2009. Anatomia foliar como subsídio à taxonomia de espécies do complexo Briza L. (Poaceae: Pooideae: Poeae). Acta Bot. Brasilica 23: 666-680. doi:10.1590/S010233062009000300006.

Peraza-Flores, L. N., Fernández-Concha, G. C., and RomeroGonzález, G. A. 2011. Taxonomic notes in American Polystachya (Orchidaceae): the identity of P. foliosa (Hook.) Rchb.f. and the reestablishment of P. caracasana Rchb.f. J. Torrey Bot. Soc. 138: 366-380. doi:10.3159/TORREY-D-1100029.1.

Pereira, A. C. S., Borba, E. L., and Giulietti, A. M. 2007. Genetic and morphological variability of the endangered Syngonanthus mucugensis Giul. (Eriocaulaceae) from the Chapada Diamantina, Brazil: implications for conservation and taxonomy. Bot. J. Linn. Soc. 153: 401-416. doi:10.1111/j.10958339.2007.00624.x
Perret, M., Chautems, A., Spichiger, R., Barraclough, T. G., and Savolainen, V. 2007. The geographical pattern of speciation and floral diversification in the neotropics: The tribe Sinningieae (Gesneriaceae) as a case study. Evolution 61: 1641-1660. doi:10.1111/j.1558-5646.2007.00136.x.

Pessoa, E. M., Alves, M., Alves-Araújo, A., Palma-Silva, C., and Pinheiro, F. 2012. Integrating different tools to disentangle species complexes: a case study in Epidendrum (Orchidaceae). Taxon 61: 721-734.

Petit, R. J., and Excoffier, L. 2009. Gene flow and species delimitation. Trends Ecol. Evol. 24: 386-393. doi:10.1016/j. tree.2009.02.011.

Pinheiro, F., and Barros, F. de. 2007. Morphometric analysis of Epidendrum secundum (Orchidaceae) in southeastern Brazil. Nord. J. Bot. 25: 129-136. doi:10.1111/j.0107055X.2007.00010.x.

Pinheiro, F., and Barros, F. de. 2009. Morphometric analysis of the Brasiliorchis picta complex (Orchidaceae). Rev. Bras. Botânica 32: 11-21.

Pinheiro, F., Koehler, S., Corrêa, A. M., Salatino, M. L. F., Salatino, A., and Barros, F. de. 2009. Phylogenetic relationships and infrageneric classification of Epidendrum subgenus Amphiglottium (Laeliinae, Orchidaceae). Plant Syst. Evol. 283: 165-177. doi:10.1007/s00606-0090224-2.

Pinheiro, F., Cozzolino, S., Barros, F. de, Gouveia, T. M. Z. M., Suzuki, R. M., Fay, M. F., and Palma-Silva, C. 2013. Phylogeographic structure and outbreeding depression reveal early stages of reproductive isolation in the neotropical orchid Epidendrum denticulatum. Evol. Int. J. Org. Evol. 67: 2024-39. doi:10.1111/evo.12085.

Pinheiro, F., Cafasso, D., Cozzolino, S., and Scopece, G. 2015. Transitions between self-compatibility and self-incompatibility and the evolution of reproductive isolation in the large and diverse tropical genus Dendrobium (Orchidaceae). Ann. Bot. 116: 457467. doi:10.1093/aob/mcv057.

Pinheiro, F., Gouveia, T. M. Z. de M., Cozzolino, S., Cafasso, D., Cardoso-Gustavson, P., Suzuki, R. M., and Palma-Silva, C. 2016. Strong but permeable barriers to gene exchange between sister species of Epidendrum. Am. J. Bot. 103: 1472-1482. doi:10.3732/ajb.1600064.

Pinheiro, M., and Miotto, S. T. S. 2005. Lupinus reitzii (Fabaceae-Faboideae), a new species of the Lupinus lanatus complex from southern Brazil. Novon 15: 346-349.

Planchuelo, A. M., and Dunn, D. B. 1989. Two new species of the Lupinus lanatus complex. Ann. Missouri Bot. Gard. 76: 303. doi:10.2307/2399349.

Pons, J., Barraclough, T. G., Gomez-Zurita, J., Cardoso, A., Duran, D. P., Hazell, S., Kamoun, S., Sumlin, W. D., and Vogler, A. P. 2006. Sequence-based species delimitation for the DNA taxonomy of undescribed insects. Syst. Biol. 55: 595-609. doi:10.1080/10635150600852011.

Porter-Utley, K. 2014. A revision of Passiflora L. subgenus Decaloba (DC.) Rchb. supersection Cieca (Medik.) J. M. MacDougal \& Feuillet (Passifloraceae). PhytoKeys 43: 1-224. doi:10.3897/phytokeys.43.7804.

Pritchard, J. K., Stephens, M., and Donnelly, P. 2000. Inference of population structure using multilocus genotype data. Genetics 155: 945-59.

Prohens, J., Anderson, G. J., Blanca, J. M., Cañizares, J., Zuriaga, E., and Nuez, F. 2006. The implications of AFLP data for the systematics of the wild species of Solanum section 
Basarthrum. Syst. Bot. 31: 208-216. doi:10.1600/ 036364406775971822.

Puillandre, N., Modica, M. V., Zhang, Y., Sirovich, L., Boisselier, M. C., Cruaud, C., Holford, M., and Samadi, S. 2012. Large-scale species delimitation method for hyperdiverse groups. Mol. Ecol. 21: 2671-2691. doi:10.1111/j.1365294X.2012.05559.x.

Ribeiro, P. L., Borba, E. L., Smidt, E. C., Lambert, S. M., Schnadelbach, A. S., and Berg, C. van den. 2008. Genetic and morphological variation in the Bulbophyllum exaltatum (Orchidaceae) complex occurring in the Brazilian "campos rupestres": Implications for taxonomy and biogeography. Plant Syst. Evol. 270: 109-137. doi:10.1007/s00606-0070603-5.

Rieseberg, L. H., Church, S. A., and Morjan, C. L. 2004. Integration of populations and differentiation of species. New Phytol. 161: 59-69. doi:10.1046/j.14698137.2003.00933.x.

Ritz, C. M., Martins, L., Mecklenburg, R., Goremykin, V., and Hellwig, F. H. 2007. The molecular phylogeny of Rebutia (Cactaceae) and its allies demonstrates the influence of paleogeography on the evolution of South American mountain cacti. Am. J. Bot. 94: 1321-1332. doi:10.3732/ ajb.94.8.1321.

Rivadavia, F., Gonella, P. M., Sano, P. T., and Fleischmann, A. 2014. Elucidating the controversial Drosera montana complex (Droseraceae): a taxonomic revision. Phytotaxa 172: 141-175. doi:10.11646/phytotaxa.172.3.1.

Rodrigues, J. F., Berg, C., Abreu, A. G., Novello, M., Veasey, E. A., Oliveira, G. C. X., and Koehler, S. 2015. Species delimitation of Cattleya coccinea and C. mantiqueirae (Orchidaceae): insights from phylogenetic and population genetics analyses. Plant Syst. Evol. 301: 1345-1359. doi:10.1007/ s00606-014-1156-z.

Roncal, J., Francisco-Ortega, J., and Lewis, C. E. 2007. An evaluation of the taxonomic distinctness of two Geonoma macrostachys (Arecaceae) varieties based on intersimple sequence repeat (ISSR) variation. Bot. J. Linn. Soc. 153: 381-392. doi:10.1111/j.1095-8339.2007.00619.x.

Sampaio, J. A. T., Paggi, G. M., Zanella, C. M., Bruxel, M., Palma-Silva, C., Goetze, M., Büttow, M. V., and Bered, F. 2012. Inbreeding depression in Vriesea gigantea, a perennial bromeliad from southern Brazil. Bot. J. Linn. Soc. 169: 312319. doi:10.1111/j.1095-8339.2012.01240.x.

Särkinen, T., Barboza, G. E., and Knapp, S. 2015. True black nightshades: phylogeny and delimitation of the morelloid clade of Solanum. Taxon 64: 945-958. doi:10.12705/645.5.

Sawyer, N. W., and Rojas, C. E. B. 1998. Morphological analysis of three equivocal sibling species of Deprea (Solanaceae). Brittonia 50: 524. doi:10.2307/2807764.

Schmidt-Lebuhn, A. N. 2007. Using amplified fragment length polymorphism (AFLP) to unravel species relationships and delimitations in Minthostachys (Labiatae). Bot. J. Linn. Soc. 153: 9-19. doi:10.1111/j.10958339.2007.00588.x.

Schulman, L., Koivunen, H., and Ruokolainen, K. 2004. Spatioecological niche segregation of two sympatric species of $\mathrm{Cli}$ demia (Melastomataceae) in western Amazonian nonflooded rainforests. Folia Geobot. 39: 143-160. doi:10.1007/ BF02805243.
Scopece, G., Lexer, C., Widmer, A., and Cozzolino, S. 2010. Polymorphism of postmating reproductive isolation within plant species. Taxon 59: 1367-1374.

Scotti-Saintagne, C., Dick, C. W., Caron, H., Vendramin, G. G., Guichoux, E., Buonamici, A., Duret, C., Sire, P., Valencia, R., Lemes, M. R., Gribel, R., and Scotti, I. 2013. Phylogeography of a species complex of lowland Neotropical rain forest trees (Carapa, Meliaceae). J. Biogeogr. 40: 676-692. doi:10.1111/j.1365-2699.2011.02678.x.

Scrivanti, L. R., Caponio, I., Anton, A. M., and Norrmann, G. A. 2010. Chromosome number in South American species of Bothriochloa (Poaceae: Andropogoneae) and evolutionary history of the genus. Plant Biol. 12: 910-916. doi:10.1111/j.1438-8677.2009.00314.x.

Seehausen, O., Butlin, R. K., Keller, I., Wagner, C. E., Boughman, J. W., Hohenlohe, P. A., Peichel, C. L., Saetre, G.-P., Bank, C., Brännström, A., Brelsford, A., Clarkson, C. S., Eroukhmanoff, F., Feder, J. L., Fischer, M. C., Foote, A. D., Franchini, P., Jiggins, C. D., Jones, F. C., Lindholm, A. K., Lucek, K., Maan, M. E., Marques, D. A., Martin, S. H., Matthews, B., Meier, J. I., Möst, M., Nachman, M. W., Nonaka, E., Rennison, D. J., Schwarzer, J., Watson, E. T., Westram, A. M., and Widmer, A. 2014. Genomics and the origin of species. Nat. Rev. Genet. 15: 176-192. doi:10.1038/nrg3644.

Seijo, J. G., and Fernández, A. 2003. Karyotype analysis and chromosome evolution in South American species of Lathyrus (Leguminosae). Am. J. Bot. 90: 980-987. doi:10.3732/ ajb.90.7.980.

Semir, J., Loeuille, B., and Monge, M. 2014. The Lychnophora granmogolensis (Asteraceae-Vernonieae) species complex: two new species and comments on the identity of Lychnophora granmogolensis. Syst. Bot. 39: 988-996. doi:10.1600/ 036364414 X682193.

Shaffer, H. B., and Thomson, R. C. 2007. Delimiting species in recent radiations. Syst. Biol. 56: 896-906. doi:10.1080/ 10635150701772563.

Silberbauer-Gottsberger, I., Gottsberger, G., and Ehrendorfer, F. 1992. Hybrid speciation and radiation in the neotropical woody genus Tocoyena (Rubiaceae). Plant Syst. Evol. 181: 143-169. doi:10.1007/BF00937441.

Silvestro, D., Zizka, G., and Schulte, K. 2014. Disentangling the effects of key innovations on the diversification of Bromelioideae (Bromeliaceae). Evolution 68: 163-175. doi:10.1111/evo.12236

Simon, M. F., Grether, R., Queiroz, L. P. de, Särkinen, T. E., Dutra, V. F., and Hughes, C. E. 2011. The evolutionary history of Mimosa (Leguminosae): toward a phylogeny of the sensitive plants. Am. J. Bot. 98: 1201-1221. doi:10.3732/ ajb. 1000520 .

Sites, J. W., and Marshall, J. C. 2003. Delimiting species: a renaissance issue in systematic biology. Trends Ecol. Evol. 18: 462-470. doi:10.1016/S0169-5347(03)00184-8

Smith, B. T., McCormack, J. E., Cuervo, A. M., Hickerson, M. J., Aleixo, A., Cadena, C. D., Pérez-Emán, J., Burney, C. W., Xie, X., Harvey, M. G., Faircloth, B. C., Glenn, T. C., Derryberry, E. P., Prejean, J., Fields, S., Brumfield, R. T. 2014. The drivers of tropical speciation. Nature 515: 406-409. doi:10.1038/nature13687.

Solís-Lemus, C., Knowles, L. L., and Ané, C. 2015. Bayesian species delimitation combining multiple genes and traits in 
a unified framework. Evolution 69: 492-507. doi:10.1111/ evo.12582.

Solís-Neffa, V. G., and Fernández, A. 2001. Cytogeography of the South American Turnera sidoides L. complex (Turneraceae, Leiocarpae). Bot. J. Linn. Soc. 137: 189-196. doi:10.1006/bojl.2001.0479.

Solís-Neffa, V. G., and Fernández, A. 2002. Karyotypic studies in Turnera sidoides complex (Turneraceae, Leiocarpae). Am. J. Bot. 89: 551-558. doi:10.3732/ajb.89.4.551.

Solís-Neffa, V. G., Panseri, A. F., Reynoso, W., and Seijo, J. G. 2004. Variación del color de flores y números cromosómicos en el noroeste del área de distribución de Turnera sidoides. Bonplandia 13: 117-128.

Soltis, P. S., and Soltis, D. E. 2009. The role of hybridization in plant speciation. Annu. Rev. Plant Biol. 60: 561-588. doi:10.1146/annurev.arplant.043008.092039.

Souza, L. G. R., Crosa, O., Speranza, P., and Guerra, M. 2012. Cytogenetic and molecular evidence suggest multiple origins and geographical parthenogenesis in Nothoscordum gracile (Alliaceae). Ann. Bot. 109: 987-999. doi:10.1093/ $\mathrm{aob} / \mathrm{mcs} 020$.

Speranza, P. R., Vaio, M., and Mazzella, C. 2003. Karyotypes of two cytotypes of Paspalum quadrifarium Lam. (Poaceae): an alternative technique for small chromosomes in plants. Genet. Mol. Biol. 26: 449-503. doi:10.1590/S141547572003000400013.

Speranza, P. R., Seijo, J. G., Grela, I. A., and Solís-Neffa, V. G. 2007. Chloroplast DNA variation in the Turnera sidoides L. complex (Turneraceae): biogeographical implications. J. Biogeogr. 34: 427-436. doi:10.1111/j.1365-2699.2006.01622.x.

Stebbins, G. L. 1950. Variation and Evolution in Plants. Columbia University Press, New York.

Strelin, M. M., Cosacov, A., Diller, M., and Sérsic, A. N. 2013. Study of the polymorphism of the Patagonian Calceolaria polyrhiza (Calceolariaceae) using decision tree and sequential covering rule induction. Bot. J. Linn. Soc. 173: 487-500. doi:10.1111/boj.12078.

Sukumaran, J., and Knowles, L. L. 2017. Multispecies coalescent delimits structure, not species. Proc. Natl. Acad. Sci. 114: 1607-1612. doi:10.1073/pnas.1607921114.

Tacuatiá, L. O., Souza-Chies, T. T., Flores, A. M., Eggers, L., Siljak-Yakovlev, S., and Kaltchuk-Santos, E. 2012. Cytogenetic and molecular characterization of morphologically variable Sisyrinchium micranthum (Iridaceae) in southern Brazil. Bot. J. Linn. Soc. 169: 350-364. doi:10.1111/j.1095-8339.2012.01229.x.

Takayama, K., López-Sepúlveda, P., Greimler, J., Crawford, D. J., Peñailillo, P., Baeza, M., Ruiz, E., Kohl, G., Tremetsberger, K., Gatica, A., Letelier, L., Novoa, P., Novak, J., Stuessy, T. F. 2015. Relationships and genetic consequences of contrasting modes of speciation among endemic species of Robinsonia (Asteraceae, Senecioneae) of the Juan Fernández Archipelago, Chile, based on AFLPs and SSRs. New Phytol. 205: 415-428. doi:10.1111/nph.13000.

Tomasello, S., Álvarez, I., Vargas, P., and Oberprieler, C. 2015. Is the extremely rare Iberian endemic plant species Castrilanthemum debeauxii (Compositae, Anthemideae) a "living fossil"? Evidence from a multi-locus species tree reconstruction. Mol. Phylogenet. Evol. 82: 118-130. doi:10.1016/j. ympev.2014.09.007.

Turchetto-Zolet, A. C., Pinheiro, F., Salgueiro, F., and PalmaSilva, C. 2013. Phylogeographical patterns shed light on evolutionary process in South America. Mol. Ecol. 22: 1193-213. doi:10.1111/mec. 12164.

Turchetto, C., Segatto, A. L. A., Telles, M. P. C., Diniz-Filho, J. A. F., and Freitas, L. B. 2014. Infraspecific classification reflects genetic differentiation in the widespread Petunia axillaris complex: a comparison among morphological, ecological, and genetic patterns of geographic variation. Perspect. Plant Ecol. Evol. Syst. 16: 75-82. doi:10.1016/j. ppees.2014.01.002.

Turesson, G. 1922. The genotypical response of the plant species to the habitat. Hereditas 3: 211-350. doi:10.1111/ j.1601-5223.1922.tb02734.x.

Twyford, A. D., Kidner, C. A., and Ennos, R. 2015. Maintenance of species boundaries in a Neotropical radiation of Begonia. Mol. Ecol. 24: 4982-4993. doi:10.1111/mec.13355.

Urbani, M., Quarin, C., Espinoza, F., Penteado, M., and Rodrigues, I. 2002. Cytogeography and reproduction of the Paspalum simplex polyploid complex. Plant Syst. Evol. 236: 99-105. doi:10.1007/s00606-002-0237-6.

Vallejo-Marín, M., and Hiscock, S. J. 2016. Hybridization and hybrid speciation under global change. New Phytol. 211: 1170-1187. doi:10.1111/nph.14004.

Vázquez-Garcidueñas, S., Palacios, R. A., Segovia-Quiroz, J., Frías-Hernández, J. T., Olalde-Portugal, V., Martínez-de la Vega, O., Mollard, F. P. O., and Vázquez-Marrufo, G. 2003. Morphological and molecular data to determine the origin and taxonomic status of Prosopis chilensis var. riojana (Fabaceae, Mimosoideae). Can. J. Bot. 81: 905-917. doi:10.1139/b03-078.

Vega, Y., Marques, I., Castro, S., and Loureiro, J. 2013. Outcomes of extensive hybridization and introgression in Epidendrum (Orchidaceae): can we rely on species boundaries? PLoS One 8: e80662. doi:10.1371/journal.pone.0080662.

Versieux, L. M., and Machado, T. M. 2012. A new ornithophilous yellow-flowered Vriesea (Bromeliaceae) from Serra do Caraça, Minas Gerais, Brazil. Phytotaxa 71: 36-41. doi:10.11646/phytotaxa.71.1.7.

Via, S. 2009. Natural selection in action during speciation. Proc. Natl. Acad. Sci. 106: 9939-9946. doi:10.1073/ pnas.0901397106.

Viruel, J., Segarra-Moragues, J. G., Pérez-Collazos, E., Villar, L., and Catalán, P. 2010. Systematic revision of the Epipetrum group of Dioscorea (Dioscoreaceae) endemic to Chile. Syst. Bot. 35: 40-63. doi:10.1600/036364410790862579.

Walter, J., Vekslyarska, T., and Dobeš, C. 2015. Flow cytometric, chromosomal and morphometric analyses challenge current taxonomic concepts in the Portulaca oleracea complex (Portulacaeae, Caryophyllales). Bot. J. Linn. Soc. 179: 144-156. doi:10.1111/boj.12309.

Welker, C. A. D., Souza-Chies, T. T., Longhi-Wagner, H. M., Peichoto, M. C., McKain, M. R., and Kellogg, E. A. 2015. Phylogenetic analysis of Saccharum s.l. (Poaceae; Andropogoneae), with emphasis on the circumscription of the South American species. Am. J. Bot. 102: 248-263. doi:10.3732/ ajb.1400397.

Wet, J. M. J. 1968. Biosystematics of the Bothriochloa barbinodis complex (Gramineae). Am. J. Bot. 55: 1246-1250. doi:10.1002/j.1537-2197.1968.tb07492.x.

Wiens, J. J. 2007. Species delimitation: new approaches for discovering diversity. Syst. Biol. 56: 875-878., doi:10.1080/ 10635150701748506. 
Wilkins, J. S. 2009. Species: A History of the Idea. University of California Press, Berkeley.

Willis, S. C. 2017. One species or four? Yes!... and, no. Or, arbitrary assignment of lineages to species obscures the diversification processes of Neotropical fishes. PLoS One 12: 1-26. doi:10.1371/journal.pone.0172349.

$\mathrm{Wu}, \mathrm{C}$. I. 2001. The genic view of the process of speciation. J. Evol. Biol. 14: 851-865. doi:10.1046/j.1420-9101.2001.00335.x.

Yang, Z. 2015. The BPP program for species tree estimation and species delimitation. Curr. Zool. 61: 854-865. doi:10.1093/ czoolo/61.5.854.

Yang, Z., and Rannala, B. 2010. Bayesian species delimitation using multilocus sequence data. Proc. Natl. Acad. Sci. 107: 9264-9269. doi:10.1073/pnas.0913022107.

Zaitlin, D., and Pierce, A. J. 2010. Nuclear DNA content in Sinningia (Gesneriaceae); intraspecific genome size variation and genome characterization in S. speciosa. Genome 53: 1066-1082. doi:10.1139/G10077.

Zapata, F., and Jiménez, I. 2012. Species delimitation: inferring gaps in morphology across geography. Syst. Biol. 61: 179194. doi:10.1093/sysbio/syr084.

Zappi, D. C., Ranzato Filardi, F. L., Leitman, P., Souza, V. C., Walter, B. M. T., Pirani, J. R., Morim, M. P., Queiroz, L. P., Cavalcanti, T. B., Mansano, V. F., Forzza, R. C. 2015. Growing knowledge: an overview of seed plant diversity in Brazil. Rodriguesia 66: 1085-1113. doi:10.1590/21757860201566411.

Zuntini, A. R., Taylor, C. M., and Lohmann, L. G. 2015. Deciphering the neotropical Bignonia binata species complex (Bignoniaceae). Phytotaxa 219: 069-077. doi:10.11646/ phytotaxa.219.1.5. 